\title{
Stable isotopes in caves over altitudinal gradients: fractionation behaviour and inferences for speleothem sensitivity to climate change
}

\author{
V. E. Johnston ${ }^{1}$, A. Borsato ${ }^{1}$, C. Spötl ${ }^{2}$, S. Frisia ${ }^{3}$, and R. Miorandi ${ }^{1}$ \\ ${ }^{1}$ Geology Section, Museo delle Scienze, Via Calepina 14, 38122 Trento, Italy \\ ${ }^{2}$ Institut für Geologie und Paläontologie, Universität Innsbruck, Innrain 52, 6020 Innsbruck, Austria \\ ${ }^{3}$ School of Environmental and Life Sciences, University of Newcastle, Callaghan, 2308 NSW, Australia \\ Correspondence to: V. E. Johnston (vanessa.johnston@mtsn.tn.it)
}

Received: 30 July 2012 - Published in Clim. Past Discuss.: 14 August 2012

Revised: 4 December 2012 - Accepted: 17 December 2012 - Published: 22 January 2013

\begin{abstract}
The interpretation of stable isotope ratios in speleothem calcite is complex, and only in a few cases, unequivocal relationships with palaeoclimate parameters have been attained. A major issue is temperature, which has an effect on both the isotope incorporation into calcite and on environmental processes. Here, a field approach is taken, by studying the isotopic composition of calcites from monitored caves located in steep altitudinal topography in the northern Italian Alps. These create a thermal gradient $\left(3-12^{\circ} \mathrm{C}\right)$ apt to study the effects of temperature on the speleothem isotope record. Our data indicate that the magnitude of oxygen isotope disequilibrium effects, calculated as an offset from the experimentally determined equilibrium, decreases with increased elevation (cooler temperatures) and faster drip rate. Carbon isotope values exhibit ${ }^{13} \mathrm{C}$ enrichment at high altitudes (colder temperatures) and slow drip rates. The results obtained support modelling and laboratory cave analogue experiments that indicate temperature, drip rate, $p \mathrm{CO}_{2}$ and supersaturation are important factors controlling stable isotope fractionation, but also stress the significance of ventilation and evaporation in the cave environment. It is proposed that the effects on stable isotope ratios observed along the altitudinal gradient can be analogues for glacial to interglacial temperature changes in regions which were extensively glaciated in the past.
\end{abstract}

\section{Introduction}

Hydrology and temperature changes at glacial to interglacial transitions are well captured in continental settings by the oxygen and carbon isotope ratios of speleothem calcite (e.g. Wang et al., 2001; Bar-Matthews et al., 2003; Cruz et al., 2005; Cheng et al., 2009; Drysdale et al., 2009). Speleothem stable isotope (oxygen and carbon) records are often validated through monitoring of drip rate, dripwater composition, cave air $\mathrm{CO}_{2}$ concentration, morphology and geochemistry of calcite precipitates carried out in the cave where specimens used for palaeoclimate studies are sampled (e.g. Spötl et al., 2005; Baldini et al., 2006; Mattey et al., 2010; Miorandi et al., 2010; Tremaine et al., 2011). The large-amplitude environmental changes at glacial to interglacial transitions, however, involve temperature and vegetation fluctuations that extend far outside the range of present-day monitoring. Today, it is not possible to cover the entire range of glacial to interglacial temperature variations within a single cave, where the environmental conditions are typically characterised by a stable air temperature with uniform surface vegetation. The step beyond understanding how present-day conditions influence stable isotope incorporation in speleothems, which allows for a full interpretation of glacial-interglacial records, is to consider several caves, in the same climate region, characterised by a broad temperature range, which emulates that of a glacial to interglacial transition. Caves located at different altitudes in the same area are the optimal case-study, as the altitudinal change in temperature influences the vegetation cover and soil respiration. These two key parameters that 
modulate soil and cave air $p \mathrm{CO}_{2}$, calcite supersaturation and dripwater dissolved inorganic carbon (DIC), are both known to exert a control on degassing and calcite growth rate, and thus, stable isotope values (McDermott et al., 2006; Dreybrodt and Scholz, 2011). In the attempt to develop robust palaeoclimate interpretations from speleothem isotope values, the first assumption is that carbonates formed at isotopic equilibrium. This can be estimated by theoretical methods using the vibration modes of ions in the lattice (Horita and Clayton, 2007; Chacko and Deines, 2008), modelling (Romanov et al., 2008; Mühlinghaus et al., 2009; Dreybrodt and Scholz, 2011), laboratory methods (Kim and O'Neil, 1997; Dietzel et al., 2009) and cave-analogue experiments (Polag et al., 2010; Day and Henderson, 2011). Another approach is to use natural speleothems growing under controlled conditions, which allow empirical transfer functions to be derived (McDermott et al., 2006; Coplen, 2007; Tremaine et al., 2011; Fairchild and Baker, 2012). In this study, we use this empirical approach to test the sensitivity of speleothem $\delta^{18} \mathrm{O}$ and $\delta^{13} \mathrm{C}$ to high amplitude temperature changes by using recent precipitates and corresponding dripwaters collected in caves spanning an altitudinal gradient of over $1500 \mathrm{~m}$, coinciding with a temperature gradient of $9{ }^{\circ} \mathrm{C}$.

\section{Isotope modification during infiltration and speleothem growth}

Interpretation of stable isotope values in speleothems requires disentangling several signals and processes occurring at the surface, in the soil zone and aquifer, and within the cave. The complexity of the interpretation of oxygen isotope values is initially embedded in factors controlling the isotope composition of rainwater, which includes moisture source and transport pathways, then altitude and rainfall amount (Rozanski et al., 1992). The original oxygen isotope value can then be modified by evapotranspiration, water-rock interaction as infiltration flows through the soil and equilibrates with high soil $\mathrm{CO}_{2}$ partial pressures $\left(p \mathrm{CO}_{2}\right)$ derived from soil respiration, by dissolution of old carbonates in the epikarst and host-rock, and through prior calcite precipitation (McDermott, 2004; Lachniet, 2009). Due to the isotopic exchange times involved between carbonate and water, water that has a residence time of at least several days (at low temperatures) will have enough time to have regained isotopic equilibrium following carbonate dissolution, and thus be suitable for palaeoclimate work (Dreybrodt, 2011; Dreybrodt and Scholz, 2011).

As the dripwater enters the cave, $\mathrm{CO}_{2}$ picked up from the soil degasses by diffusion caused by a typically lower $p \mathrm{CO}_{2}$ in the cave atmosphere than that of the emergent dripwater. On completion of degassing to equilibrium with the cave environment, the $\mathrm{pH}$ has increased (to approximately 8.5) and the majority $(>95 \%)$ of the carbonate in solution is in the bicarbonate $\left(\mathrm{HCO}_{3}^{-}\right)$form (Dreybrodt and Scholz, 2011). This determines the stable isotope values of the DIC but has no influence on speleothem $\delta^{13} \mathrm{C}$ and $\delta^{18} \mathrm{O}$ values since calcite precipitation starts after the establishment of supersaturation (Scholz et al., 2009; Dreybrodt and Scholz, 2011). In addition to producing an increase in dripwater $\mathrm{pH}$, the degassing also causes a rise in the saturation index with respect to calcite $\left(\mathrm{SI}_{\mathrm{CC}}\right)$, which drives calcite to precipitate from the water, ultimately forming speleothems. Calcite precipitation rates are also dependent on temperature via the temperaturedependent calcium concentration in equilibrium with $p \mathrm{CO}_{2}$ in the solution (Dreybrodt, 2011). Ongoing calcite precipitation, however, causes a progressive enrichment in the heavy isotopes $\left({ }^{13} \mathrm{C}\right.$ and $\left.{ }^{18} \mathrm{O}\right)$, in a process known as Rayleigh distillation (Dreybrodt, 2008; Scholz et al., 2009; Dreybrodt and Scholz, 2011). Moreover, a large, second reservoir of oxygen molecules exists in the speleothem-forming solution that can readily exchange with the carbonate species in solution. Therefore, any carbonate species in oxygen isotope disequilibrium will return to isotopic equilibrium with the oxygen in the water solution through this buffer reaction (Dreybrodt, 2008).

Modelling of the solution film on the stalagmite surface indicates that during fractionation, carbon isotope values exhibit most reliance on drip rate at the stalactite tip (drip interval), whereas oxygen isotope values are more dependent on temperature, since the buffering reaction attenuates their dependence on drip rate (Mühlinghaus et al., 2009). Other parameters that may come into play include drip height and stalagmite surface morphology, which together control the amount of mixing between subsequent drips, the $p \mathrm{CO}_{2}$ of both the cave atmosphere and that dissolved in the dripwater and evaporation controlled by wind velocity (Mühlinghaus et al., 2009; Deininger et al., 2012). Cave analogue laboratory experiments confirm the results of modelling studies, indicating that higher $\delta^{18} \mathrm{O}$ values than those calculated using fractionation factors, corresponded with rapid depletion of the DIC reservoir, an increased temperature, enhanced evaporation and a slower drip rate (Polag et al., 2010; Day and Henderson, 2011).

Thus, our approach of using caves covering an elevation range of ca. $1500 \mathrm{~m}$, corresponding to a temperature range of $9^{\circ} \mathrm{C}$, where drip rate, and cave air $p \mathrm{CO}_{2}$ are known, should allow us to test the magnitude and controlling factors of isotopic disequilibrium fractionation. Our empirical approach is then tested against theoretical, modelling and experimental results, and implications for palaeoclimate studies are finally drawn.

\section{Altitudinal transect}

The studied caves developed within dolomites (Late Triassic Dolomia Principale) and limestones (Early Jurassic Calcari Grigi) (Table 1). The positive $\delta^{13} \mathrm{C}$ values of the host rocks indicate diagenesis occurred under marine and 
Table 1. Location and characteristics of caves.

\begin{tabular}{|c|c|c|c|c|c|c|c|c|}
\hline Cave & & $\begin{array}{l}\text { Altitude } \\
\text { (m a.s.l.) }\end{array}$ & $\begin{array}{r}\text { Infiltration } \\
\text { elevation } \\
(\mathrm{m} \text { a.s.l. })^{\mathrm{a}}\end{array}$ & Aspect & $\begin{array}{l}\text { Host } \\
\text { rock }^{\mathrm{b}}\end{array}$ & $\begin{array}{r}\text { Soil } \\
\text { depth } \\
(\mathrm{cm})\end{array}$ & $\mathrm{SI}_{\mathrm{cc}}$ range $^{\mathrm{c}}$ & Vegetation type \\
\hline Bus del Diaol & DL & 225 & 355 & W & CG & 80 & $0.44-0.68$ & Holm oak forest \\
\hline $\begin{array}{l}\text { Grotta della } \\
\text { Bigonda }\end{array}$ & BG & 360 & 900 & $\mathrm{~N}$ & DP & 100 & $0.12-0.50$ & $\begin{array}{l}\text { Mixed broadleaf/ } \\
\text { conifer forest }\end{array}$ \\
\hline $\begin{array}{l}\text { Grotta della } \\
\text { Fosca }\end{array}$ & FS & 620 & $650-1300$ & $\mathrm{~W}$ & DP & 80 & n.a. ${ }^{d}$ & $\begin{array}{l}\text { Mixed beech/ } \\
\text { conifer forest }\end{array}$ \\
\hline Grotta Moline & MO & 680 & $1000-2500$ & SE & CG & 80 & $-0.08-0.32$ & $\begin{array}{l}\text { Conifer forest/ } \\
\text { herbs }\end{array}$ \\
\hline $\begin{array}{l}\text { Grotta Cogola } \\
\text { di Giazzera }\end{array}$ & GZ & 1025 & 1050 & SW & $\begin{array}{l}\mathrm{CG} \\
+\mathrm{dol}\end{array}$ & 40 & $0.21-0.39$ & $\begin{array}{l}\text { Mixed beech/ } \\
\text { conifer forest }\end{array}$ \\
\hline $\begin{array}{l}\text { Grotta di } \\
\text { Ernesto }\end{array}$ & ER & 1165 & 1200 & $\mathrm{NE}$ & $\begin{array}{l}\text { CG } \\
+ \text { dol }\end{array}$ & 100 & $0.00-0.50$ & $\begin{array}{l}\text { Mixed beech/ } \\
\text { conifer forest }\end{array}$ \\
\hline Abisso Spiller & SP & 1700 & 1700 & plateau & CG & 30 & $-0.02-0.06$ & $\begin{array}{l}\text { Conifer forest/ } \\
\text { Pastures }\end{array}$ \\
\hline $\begin{array}{l}\text { Grotta Cesare } \\
\text { Battisti }\end{array}$ & $\mathrm{CB}$ & 1880 & 1930 & $\mathrm{NE}$ & CG & 20 & $-0.27-0.13$ & $\begin{array}{l}\text { Dwarf pine, herbs } \\
\text { and shrubs }\end{array}$ \\
\hline
\end{tabular}

${ }^{a}$ Note that the thickness of the overburden can be calculated approximately as the infiltration elevation minus cave entrance altitude.

b CG: Calcari Grigi limestone, DP: Dolomia Principale dolomite, dol: unspecified dolomite.

${ }^{c}$ Saturation index with respect to calcite estimated from previous long-term monitoring (Borsato et al., 2007b; Miorandi et al., 2010). The range

includes numerous samples from each cave, varying both temporally (e.g. seasonally, annually) and spatially (i.e. different drip sites).

${ }^{d}$ Data not available for this cave site.

modified marine waters; with Dolomia Principale $\delta^{13} \mathrm{C}$ varying between 0 and $+3 \%$, and $\delta^{18} \mathrm{O}$ from -6 to $+3 \%$ (Frisia and Wenk, 1993), and Calcari Grigi $\delta^{13} \mathrm{C}$ varying between +1 and $+3 \%$, and $\delta^{18} \mathrm{O}$ from -6 to $-2 \%$ (Borsato et al., 1994). The caves open within two valleys in Trentino: the main $\mathrm{N}-\mathrm{S}$ running Adige Valley and the steep $\mathrm{E}-\mathrm{W}$ running Valsugana Valley. The Adige Valley hosts the GZ and CB caves (Fig. 1, Table 1). The DL cave is located in the (N-S) Sarca Valley near Lake Garda, and the MO cave is situated in a N-S Molveno Lake Valley (parallel to the Adige Valley). The Valsugana Valley contains the BG and ER caves with the SP cave located above on the Asiago Plateau, the largest karst plateau in Italy (Fig. 1b). The FS cave is the only site lying at a distance from the other caves to the north of Valsugana Valley.

The vegetation above the caves reflects altitude (temperature), but also local microclimate (Fig. 1). Above 1500 to $1700 \mathrm{~m}$, depending on slope orientation, the mixed deciduous forest transitions into the conifer forest, with the presentday timber line positioned at 1800 to $1900 \mathrm{~m}$. The caves near Lake Garda are influenced by a Mediterranean climate, with a dry, warm summer and a cool, wetter autumn and winter, where temperatures rarely fall below freezing. By contrast, caves in the mountain ranges and plateaus span from temperate-humid to Alpine (high altitude) climates (Table 1).

The thickness of the rock overburden varies for the cave sites, with some having a shallow overburden (e.g. ER, GZ and $\mathrm{CB}$ ), whereas others are deeper (e.g. BG, MO and SP).
At these deeper sites, the catchment of the infiltration water is at a much higher elevation relative to the cave entrance due to the topography. The actual altitude of the catchment is hereafter defined the "infiltration elevation" (see Table 1 for values).

Mean annual air temperature, recorded between 1961 and 1990 , in the Adige Valley at Trento ( $312 \mathrm{~m}$ a.s.l.) was $12.3^{\circ} \mathrm{C}$ (similar to the low altitude DL cave), while in the Valsugana Valley the temperature at Levico Terme (502 m a.s.l.; Fig. 1) was $11.0^{\circ} \mathrm{C}$ (near to the $\mathrm{BG}$ cave). In winter months, mean temperatures at these valley bottom sites lie just above freezing, while in summer they reach around $20^{\circ} \mathrm{C}$. By contrast, at high altitudes the mean annual air temperature was $1.7^{\circ} \mathrm{C}$ on Paganella Mountain (2125 ma.s.l.) (at the CB cave entrance) and $7.3^{\circ} \mathrm{C}$ at Lavarone (1155 ma.s.l.) on the Asiago Plateau (near to the SP cave) (Fig. 1). Winter freezing temperatures last between November and April on Paganella Mountain, and from January to February at lower altitude Lavarone. Precipitation mean values over the same period were $931 \mathrm{~mm} \mathrm{yr}^{-1}$ at Trento, $1017 \mathrm{~mm} \mathrm{yr}^{-1}$ at Levico Terme, and $1308 \mathrm{~mm} \mathrm{yr}^{-1}$ at Lavarone (www.meteotrentino.it).

\section{Methods}

All caves were sampled during September 2010, with the exception of the MO cave (February 2011) and the DL cave that could not be entered until August 2012 due to flooding 


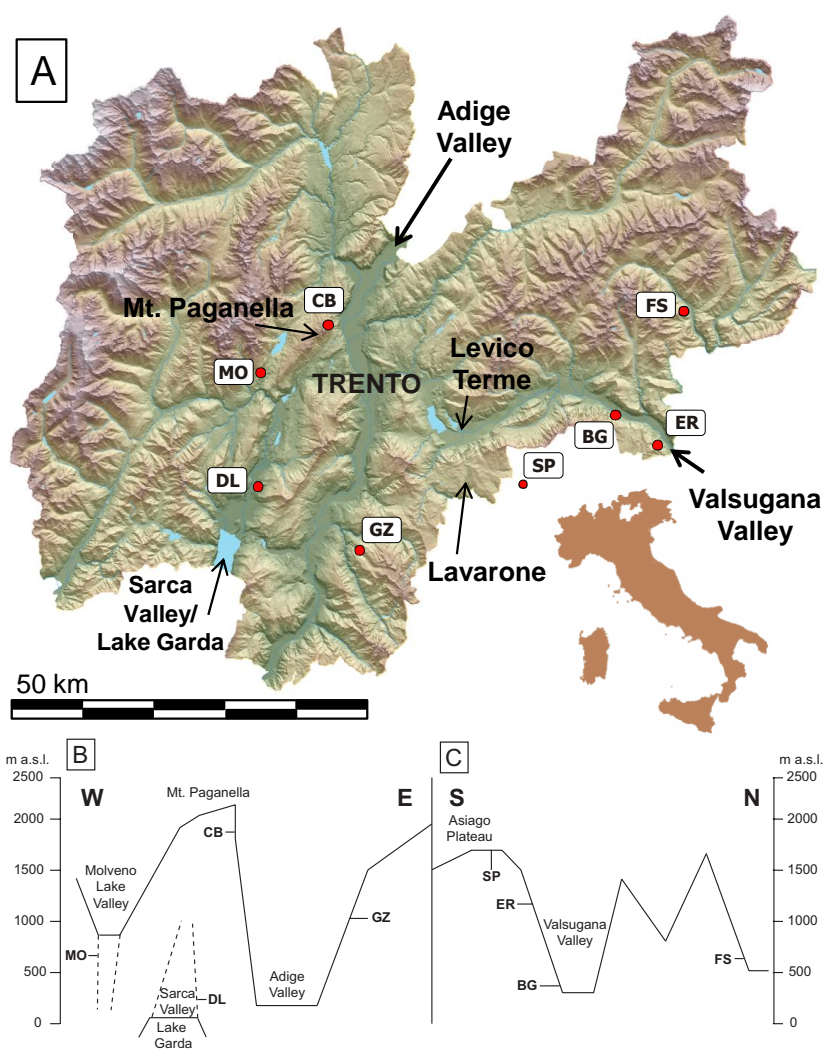

Fig. 1. Location of cave sites in Trentino, N. Italy. (A) Map of Trentino with cave sites and main valleys marked. Note SP cave is just in the Veneto region. Locations of meteorological data (Trento, Levico Terme, Lavarone and Mt. Paganella) also indicated. (B) Schematic cross-section of topography to show the relative altitudes and locations of the cave sites in and around the Adige Valley. Internal valleys are noted with dashed lines. (C) Schematic crosssection of caves in the Valsugana Valley. Altitudes are to scale, horizontal length is schematic. Note that the Asiago Plateau is located on the map in the same area as the SP cave and Lavarone.

(Table 2). In addition, the BG cave was sampled in August 2010 and February 2012 (Table 2). Carrying out the majority of the sampling during a single month means that the data represent a "snapshot" in time. Therefore, when interpreting the data, temporal (seasonal and inter-annual) variability often exhibited in cave data (e.g. Miorandi et al., 2010; Frisia et al., 2011) will not need to be accounted for, although this may cause some uncertainties due to the different residence times of the infiltrating water.

During the visits, cave air temperature and cave air $p \mathrm{CO}_{2}$ concentrations were measured using a Vaisala GM70 meter with a GMP222 probe (accuracy at $25^{\circ} \mathrm{C} \pm 20 \mathrm{ppm} \mathrm{CO}$ ) at numerous points along the centre of the galleries of each of the caves, to obtain $\mathrm{CO}_{2}$ and temperature distribution throughout the passages, in addition to an understanding of the relative strengths of cave ventilation. Drip rates were timed using a stopwatch, and electrical conductivity, $\mathrm{pH}$ and water temperature were measured for the dripwaters and in cave pools. Dripwater aliquots were collected from each drip point for isotopic analyses of $\delta^{18} \mathrm{O}$ and $\delta \mathrm{D}$. Calcite powders were collected from beneath the corresponding drip points using a Dremel Stylus hand-held, battery operated drill with a diamond wheel point for isotopic analyses $\left(\delta^{18} \mathrm{O}\right.$ and $\left.\delta^{13} \mathrm{C}\right)$. On selecting drip points, only seemingly active (wet and bright) calcite precipitates were sampled, including stalagmites, flowstones and small calcite crusts (Table 2). Milling was carried out carefully to remove only surface calcite close to the point of impact.

Isotopic analyses of dripwaters and calcite powders were carried out at the University of Innsbruck, Austria, using an on-line, continuous-flow system (Gasbench II) linked to

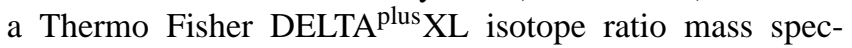
trometer. The water oxygen isotope composition was determined by equilibration with carbon dioxide and calibrated against VSMOW (Vienna Standard Mean Ocean Water), GISP (Greenland Ice Sheet Precipitation) and SLAP (Standard Light Antarctic Precipitation) standards and reported on the VSMOW scale. The $1 \sigma$ analytical uncertainty on $\delta^{18} \mathrm{O}$ values is $0.09 \%$ (Spötl et al., 2005). The calcite oxygen and carbon isotopes are reported against VPDB (Vienna Pee Dee Belemnite), and are calibrated against an in-house standard that has itself been calibrated with NBS-18, NBS-19, CO1 and CO- 8 reference materials. The long-term $1 \sigma$ standard deviation is 0.06 and $0.08 \%$ for $\delta^{13} \mathrm{C}$ and $\delta^{18} \mathrm{O}$, respectively (Spötl and Vennemann, 2003).

Petrographic observations were carried out using an optical transmission microscope and a scanning electron microscope (SEM) at the Museo delle Scienze, Trento, Italy. Calcite precipitates, including those formed on glass plates, collected during previous long-term monitoring studies at the DL and ER caves, were also analysed.

\section{Results}

\subsection{Cave air temperature, $p \mathrm{CO}_{2}$ and $\mathrm{SI}_{\mathrm{CC}}$}

Figure 2a compares the average mean air temperature, from meteorological stations over the studied elevation range, with the measured cave air temperatures. The external air temperature decreases with altitude and, in most cases, the cave air temperatures follow the external trend closely. The BG cave (and to a lower extent the FS and MO caves), however, shows lower air temperature relative to what is expected for the elevation of the cave entrance. The studied caves are within a regime of seasonal temperature contrast, and therefore cave air ventilation is to be expected, particularly in caves with descending galleries or more than one entrance (Fairchild and Baker, 2012). In these cases, cooler air from higher altitude can descend into the cave, thus significantly reducing the cave air temperatures (Luetscher and Jeannin, 2004). 


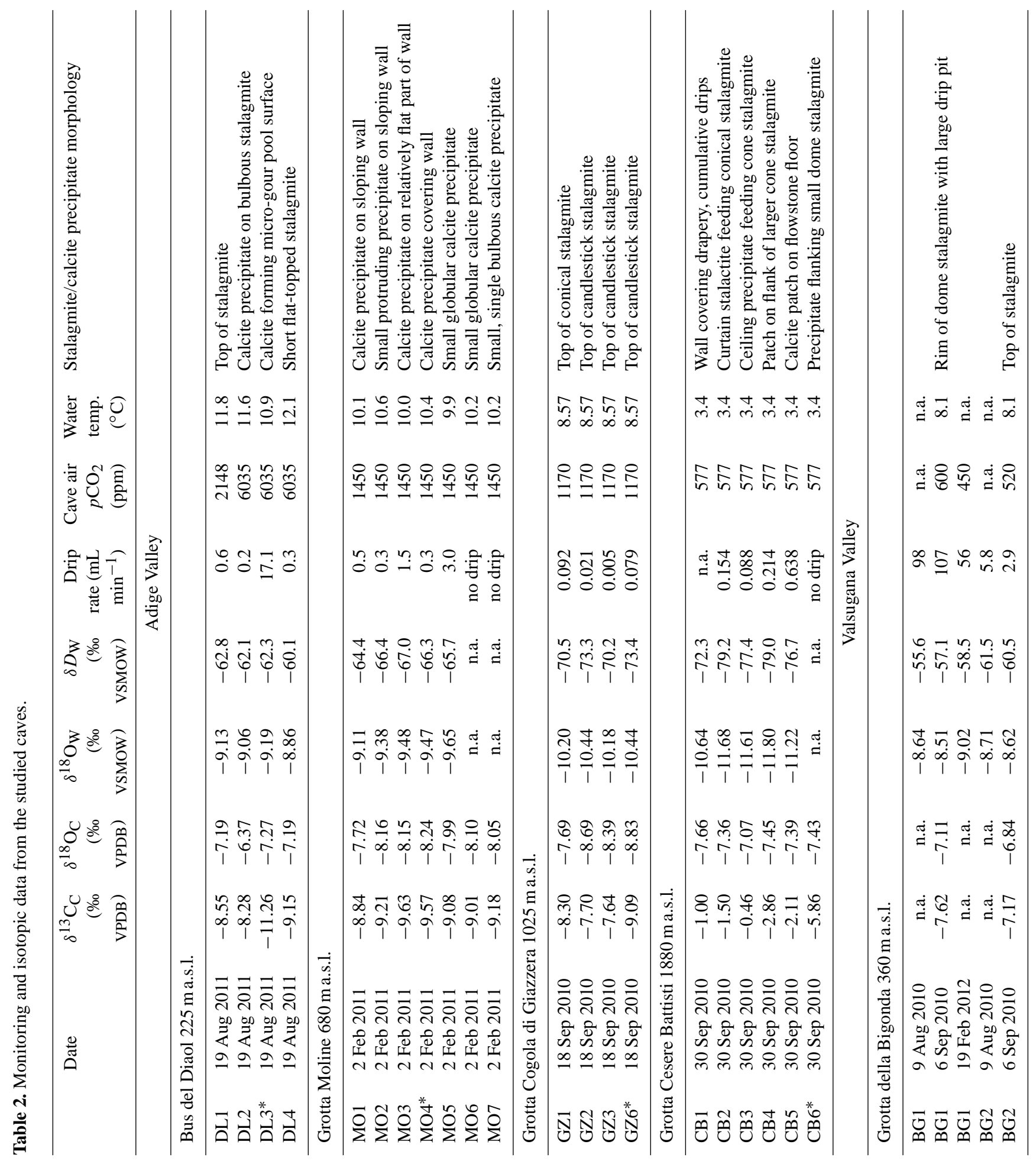




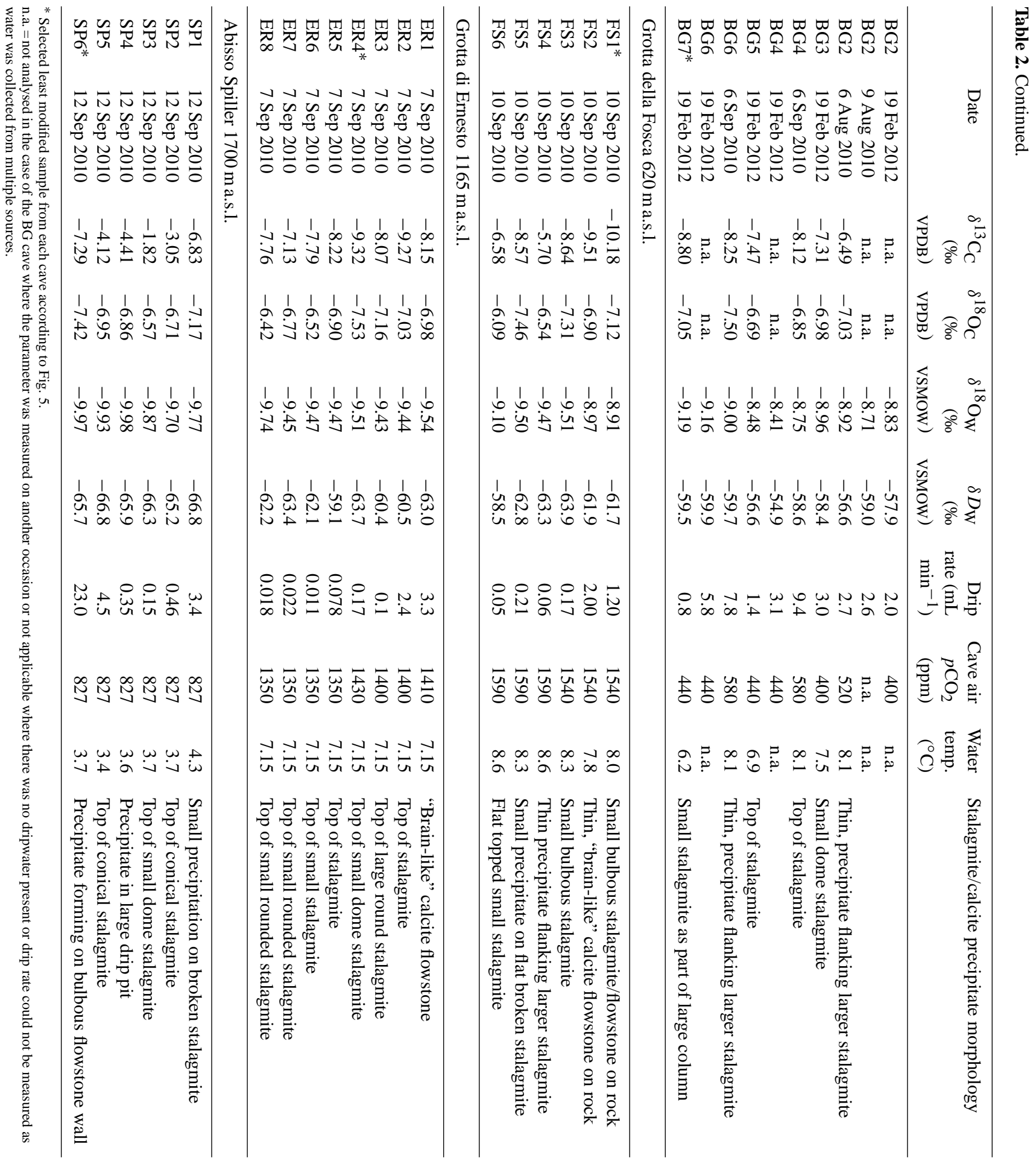



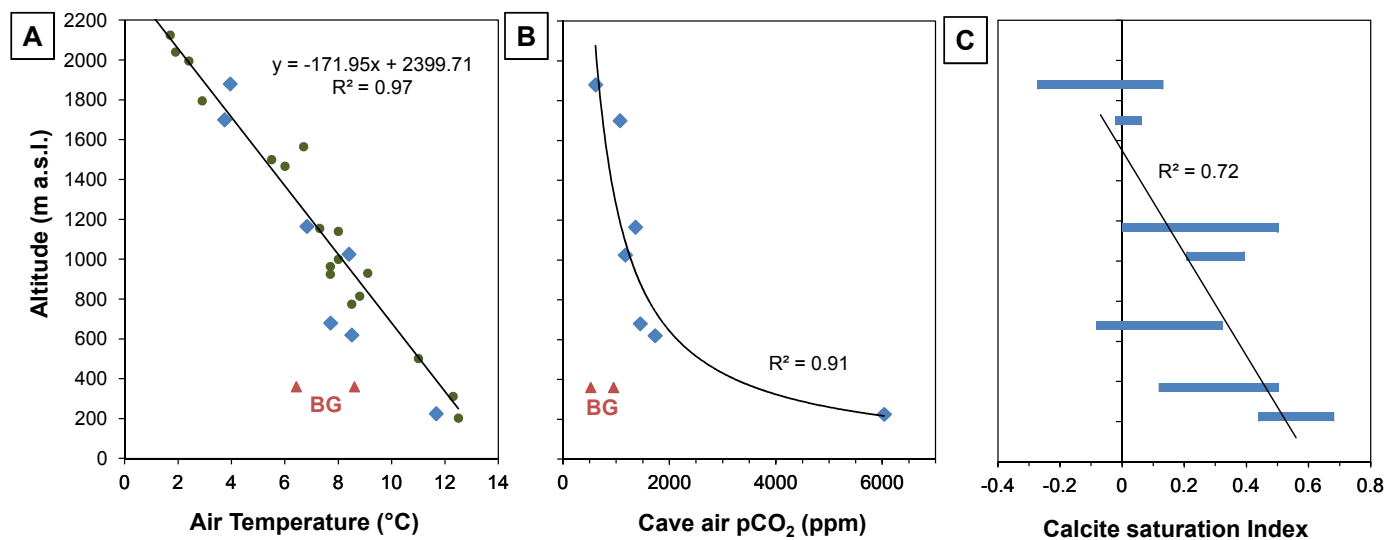

Fig. 2. Temperature, $p \mathrm{CO}_{2}$ and calcite saturation index with altitude. (A) Air temperature of meteorological stations and cave interiors against altitude. Green dots indicate average air temperature at $2 \mathrm{~m}$ over the period 1961-1990 at 19 weather stations in Trentino (www. meteotrentino.it). Blue diamonds represent the air temperature of the stable interior cave air for each of the caves (except BG) at the time of sampling. Bigonda Cave (BG red triangles; summer and winter range) falls below the expected temperature for the elevation of the cave entrance. (B) Cave air carbon dioxide concentration in main sampling chamber against cave entrance altitude. BG cave (red triangles) results are excluded from the trend. (C) Dripwater calcite saturation index ranges (Table 1) taken from previous long-term monitoring programs in the same caves (Miorandi et al., 2005, 2010; Borsato et al., 2007b).

Ventilation also strongly affects cave air $p \mathrm{CO}_{2}$ and may subsequently influence dripwater evaporation and isotope disequilibrium effects (Deininger et al., 2012). Figure 2b shows that there is a strong increase in cave air $p \mathrm{CO}_{2}$ with decreasing altitude, for most of the studied sites. The BG cave samples are an outlier to the general trend, with lower $p \mathrm{CO}_{2}$ values than expected for the cave altitude. In the $\mathrm{CB}$ cave, opening at the highest altitude relative to all cave sites studied, most passages exhibited atmospheric concentrations of $p \mathrm{CO}_{2}$, with a slight increase in $p \mathrm{CO}_{2}$ found in a small, secluded chamber, where the only, barely active, speleothem growth in the cave was observed.

Saturation index values, with respect to calcite $\left(\mathrm{SI}_{\mathrm{CC}}\right)$, were not measured in this study but have been estimated (Table 1) based on previous dripwater monitoring (Borsato et al., 2007b; Miorandi et al., 2010). These studies contain a range for sampling points in each cave, and account for seasonal and often also annual variability, that would not be represented in this snapshot study, but strongly affect $\mathrm{SI}_{\mathrm{CC}}$. These data exhibit a similar trend to that of temperature and cave air $p \mathrm{CO}_{2}$, with a general decrease in $\mathrm{SI}_{\mathrm{CC}}$ with increasing altitude (Fig. 2c). $\mathrm{SI}_{\mathrm{CC}}$ ranges for the $\mathrm{BG}$ and $\mathrm{MO}$ cave data are generally lower than expected, based on the altitudinal trend exhibited by the other cave data (Fig. 2c).

\subsection{Cave dripwater oxygen and hydrogen isotopes}

The oxygen isotope ratio values, of the dripwaters collected from all caves, exhibit a trend to more negative values with increasing altitude (Fig. 3a). The cave samples from each valley show distinct isotopic characteristics, and therefore, must be treated separately when identifying patterns and trends. Dripwaters in caves opening in the Adige Valley exhibit more negative $\delta^{18} \mathrm{O}$ values, from -11.8 to $-8.9 \%$, and a steeper altitudinal gradient $\left(\Delta \delta^{18} \mathrm{O} / 100 \mathrm{~m}=-0.15 \%\right.$ ) relative to the dripwaters in caves opening in the Valsugana Valley, which show values ranging from -10.0 to $-8.4 \%$ with a shallower altitudinal gradient $\left(\Delta \delta^{18} \mathrm{O} / 100 \mathrm{~m}=-0.08 \%\right.$ ) . A similar pattern is exhibited by the hydrogen isotopes (not shown). The dripwaters of Adige Valley caves $(-79$ to $-60 \%$ o) display a steeper altitudinal gradient $(\Delta \delta \mathrm{D} / 100 \mathrm{~m}=-0.92 \%$ ) , than those opening in the Valsugana Valley ( -67 to $-55 \%$ o), which exhibit a shallower gradient with altitude $(\Delta \delta \mathrm{D} / 100 \mathrm{~m}=-0.52 \%)$.

The altitudinal trend is also seen on a cross-plot of oxygen and hydrogen isotopes (Fig. 3b). Cave dripwater samples are slightly inclined relative to the meteoric water line (Craig, 1961), with the Adige and Valsugana Valleys having slightly differing trends. Samples from the highest altitude caves exhibit the most negative $\delta^{18} \mathrm{O}$ and $\delta \mathrm{D}$ values, which trends to the least negative isotopic values at low altitudes. However, the high altitudes of the Adige Valley exhibit much more negative values (both $\delta^{18} \mathrm{O}$ and $\delta \mathrm{D}$ ) than similarly high altitudes of the Valsugana Valley.

\subsection{Petrography}

The morphology of crystals formed on glass and speleothem fabrics from selected caves are shown in Fig. 4. All carbonates precipitated in the studied caves consist of low-Mg calcite. No aragonite or high-Mg calcite has been found, even in caves cut in dolomite. At low altitude, precipitates grown in the DL cave show large crystal sizes $(50-150 \mu \mathrm{m})$, flat, rhombohedra and stepped unstable faces, which probably result in columnar fabric during competitive growth. The measured crystal size at DL was reached in only three months, 

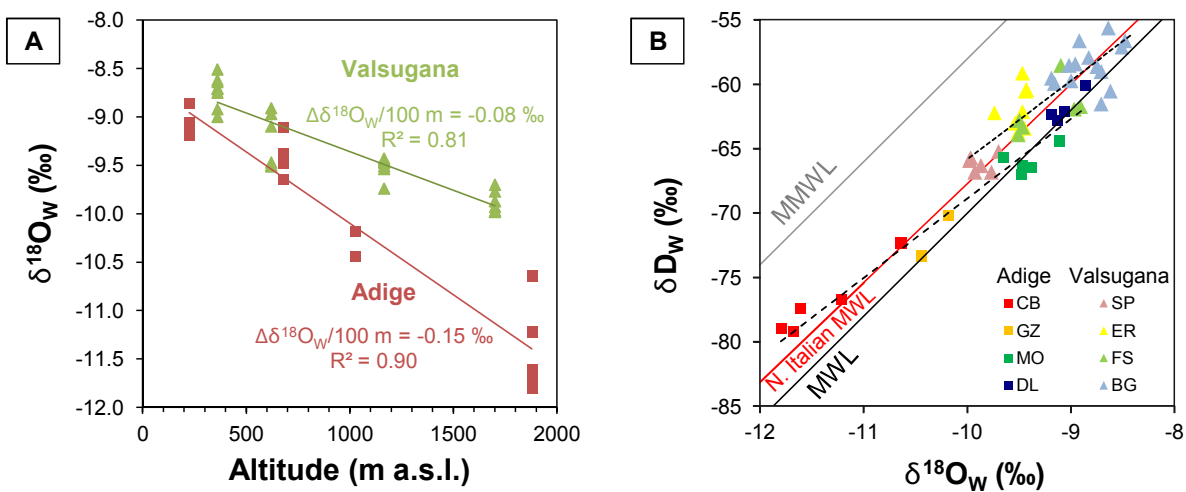

Fig. 3. Oxygen and hydrogen isotopes of the dripwaters in caves from different altitudes. (A) The oxygen isotope values deviate depending on which valley (Adige or Valsugana) the caves are situated (see Fig. 1). Hydrogen isotopes (not plotted) follow a similar pattern as the oxygen isotopes in the two valleys. (B) Dripwater oxygen vs. hydrogen isotopes align similar to the N. Italian meteoric water line (red line: Longinelli and Selmo, 2003), which lies near the global Meteoric Water Line (MWL: Craig, 1961) with a slight tendency towards the Mediterranean Meteoric Water Line (MMWL: Gat, 1996). Values align inversely with altitude, with a different trend for each valley; the Valsugana Valley trend being more condensed $\left(\delta \mathrm{D}=6.10 \times \delta^{18} \mathrm{O}-4.85 ; R^{2}=0.74\right)$ than the extensive Adige Valley trend $\left(\delta \mathrm{D}=6.17 \times \delta^{18}-7.20 ; R^{2}=0.96\right)$.
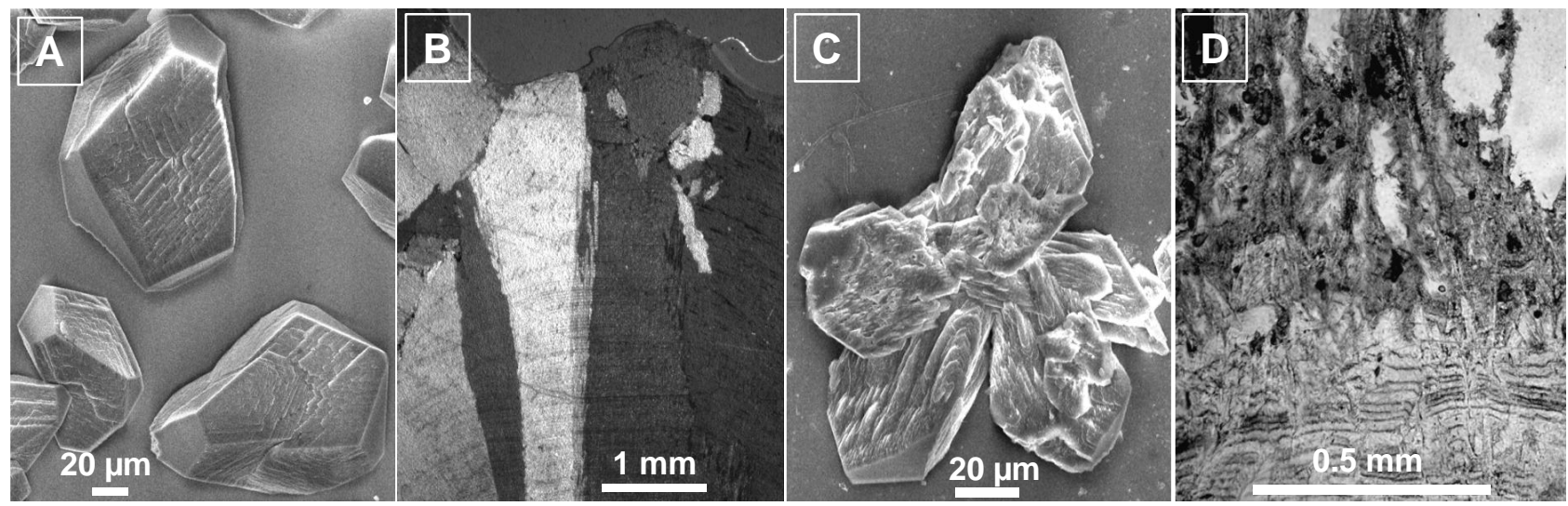

Fig. 4. Morphology of cave calcite precipitated on glass and corresponding stalagmite fabrics. (A) Calcite precipitate on glass slide collected in the DL cave between June and September 2003. The SEM image shows large crystals with flat, rhombohedra faces and stepped faces. (B) Optical microscope image (crossed polars) of the top of stalagmite SP1 from the SP cave that was active at the time of sampling (2003). Image shows columnar fabric of both compact and microcrystalline subtypes developing from crystals similar to those shown in (A). (C) Calcite precipitate on glass slide collected over a one year period in the ER cave from December 2003. The SEM image shows many macrosteps and macrokinks on the irregular faces. (D) Optical microscope image of typical fabrics of stalagmite ER77. Bottom: annually laminated microcrystalline subtype of columnar fabric grading into highly porous dendritic fabric (top) arising from irregular crystals with lateral overgrowths as shown in $(\mathbf{C})$.

indicating a relatively fast precipitation rate. Despite having formed at a different elevation, and lower temperature, stalagmite Stal-SP1 from the SP cave exhibits columnar fabric, similar to that expected from the precipitates of the low altitude DL cave (Fig. 4b). Precipitates grown on glass slides at the ER cave (Fig. 4c) display irregular faces interrupted by macrosteps and macrokinks, which may result in a wide variety of fabrics, from columnar to dendritic, as a response to the impurities which may poison growth sites (Frisia et al., 2000). At the ER cave, one year was required to obtain a similar weight of calcite to that reached after just three months at the DL cave. The low ER cave calcite growth rate reflects the low calcite supersaturation (Fairchild et al., 2000), and renders these mid-altitude speleothems more sensitive to the effects of impurities when the drips are barely saturated. Stalagmite ER77, in fact, exhibits a change in fabric from columnar (microcrystalline subtype) to dendritic (Fig. 4d). One of the results of petrography observations is that temperature does not affect the fabrics, but as already demonstrated for the ER cave (Frisia et al., 2003), the growth rate does. What influences the fabrics is the balance between supersaturation and infiltration of impurities. 


\subsection{Oxygen and carbon isotopes of calcite}

Oxygen and carbon isotopes measured on apparently active calcite precipitates exhibit values ranging from -8.8 to -6.1 $\%$ and -0.5 to $-11.3 \%$, respectively (Table 2 ). Most of the observed spread of isotopic values is clearly related to the diverse altitudinal setting. The calcite oxygen isotopes trend to more negative values at high altitudes due to surface air temperature cooling through the orographic (altitude) effect on meteoric precipitation (Bowen and Wilkinson, 2002). Whereas in-cave oxygen isotope fractionation has been shown to cause an increased oxygen isotope value with decreasing temperatures (Mühlinghaus et al., 2009), clearly trending in the opposite direction to that seen in the data presented here. In order to account for the effects of surface cooling (altitude) on the water isotopes, and thus enable the identification of in-cave fractionation, throughout this study the oxygen isotope fractionation will be viewed using terms such as $1000 \ln \alpha_{\text {calcite-water }}$ that essentially normalises for the water isotopes.

Each cave also exhibits a spread of calcite isotope values that exceeds $1 \% \circ$ in $\delta^{18} \mathrm{O}$ and $5 \%$ in $\delta^{13} \mathrm{C}$ (Fig. 5). It is reasonable to infer that the in-cave variability reflects kinetic processes related to rapid calcite precipitation, long drip intervals and evaporation (Mickler et al., 2006; Day and Henderson, 2011; Dreybrodt and Scholz, 2011). To allow a better identification of altitudinal trends, the noise that is introduced to the data by the in-cave fractionation effects must be reduced. To do this, one sample from each cave has been chosen that is assumed to be least affected by kinetic processes, which will represent the site without in-cave fractionation. The chosen sample generally has the most negative isotopic values and we use both $\delta^{13} \mathrm{C}$ and $\delta^{18} \mathrm{O}$ from the samples circled in Fig. 5.

\section{Discussion}

\subsection{Cave air temperature, $p \mathrm{CO}_{2}$ and $\mathrm{SI}_{\mathrm{CC}}$}

The important influence that temperature exerts on stable isotope values, particularly oxygen isotopes, during calcite precipitation from the solution layer on stalagmites has been demonstrated in modelling studies (e.g. Mühlinghaus et al., 2009). Here, cave interior air temperature is shown to decrease with altitude, similar to the mean annual (outside) air temperature (Fig. 2a). However, for the BG cave, and also to a lesser extent the MO and FS caves, the cave air temperatures are lower than expected from the trend. This cooler temperature can be reasonably explained by rapid infiltration of cold water and meltwater from an infiltration elevation much higher than the cave entrance (Table 1). The very large fluxes of cooler water entering the deep vadose zone of the BG cave causes a major cooling of the cave air temperature (cf. Luetscher and Jeannin, 2004). The large temperature gradients established though the cave cause strong ventilation (as felt in the BG cave), which may considerably increase evaporation from the solution layer on top of forming speleothems, enhancing isotope disequilibrium effects (Day and Henderson, 2011; Deininger et al., 2012).

Cave air $p \mathrm{CO}_{2}$ shows a strong trend to higher values at lower altitudes (Fig. 2b), where a thick soil cover, and warmer temperatures promote soil respiration, given that none of the caves experiences severe moisture stress (Fairchild and Baker, 2012). Importantly, a thick soil cover seals off $\mathrm{CO}_{2}$ loss from the epikarst, with atmospheric $\mathrm{CO}_{2}$ exchange only occurring in the upper soil zone. Therefore, a large proportion of the $\mathrm{CO}_{2}$ produced is transferred downwards, towards the cave, rather than being released into the atmosphere. The BG cave exhibits significantly lower cave air $p \mathrm{CO}_{2}$ than expected for its entrance elevation, the soil thickness and vegetation type on the valley slope ( $\mathrm{Ta}-$ ble 1). This can be logically ascribed to strong ventilation (wind tube), which may suggest samples in this cave undergo enhanced evaporation and disequilibrium isotope fractionation (Day and Henderson, 2011; Deininger et al., 2012). At higher altitudes, the $p \mathrm{CO}_{2}$ in the caves trends towards atmospheric values due to thin, patchy soil, reduced vegetation cover, shorter summer periods and, therefore, low $\mathrm{CO}_{2}$ production/downward-transmission rates. Stronger ventilation is also found in superficial caves at high altitudes due to a more fractured rock overburden, in addition to the patchy soil that allows the easy passage of air through fissures into cave chambers.

Dripwater $\mathrm{SI}_{\mathrm{CC}}$ influences isotope fractionation in our studied calcites, as should be expected, since carbonate precipitation rate is driven by the saturation state of the dripwater (Scholz et al., 2009; Dreybrodt and Scholz, 2011). A strong correlation is observed in Fig. 2 between increasing altitude with decreasing temperature, $p \mathrm{CO}_{2}$ and $\mathrm{SI}_{\mathrm{CC}}$. A decreasing precipitation rate, caused by the reducing supersaturation at higher altitudes, should reduce the deviation from isotopic equilibrium, increasing the fractionation factor $\left(\alpha_{\text {calcite-water }}\right)$. The decrease in temperature with altitude, that has been shown to have the largest effect on oxygen isotopes (Mühlinghaus et al., 2009), should increase the fractionation factor, bringing the calcite closer to equilibrium.

\subsection{Petrography}

Fabrics can give an indication of saturation state and discharge variability of the cave drip that formed a speleothem. These two factors are key in determining the degree of isotopic fractionation, as they control carbonate precipitation rate and drip interval (Mühlinghaus et al., 2009). In our interpretation, calcite speleothem fabric types are simplified into two end-members: columnar and dendritic.

The columnar end-member has been found to develop for moderate and stable saturation states $\left(\mathrm{SI}_{\mathrm{CC}}<0.5\right)$ with a low discharge variability, in addition to a low input of impurities, 

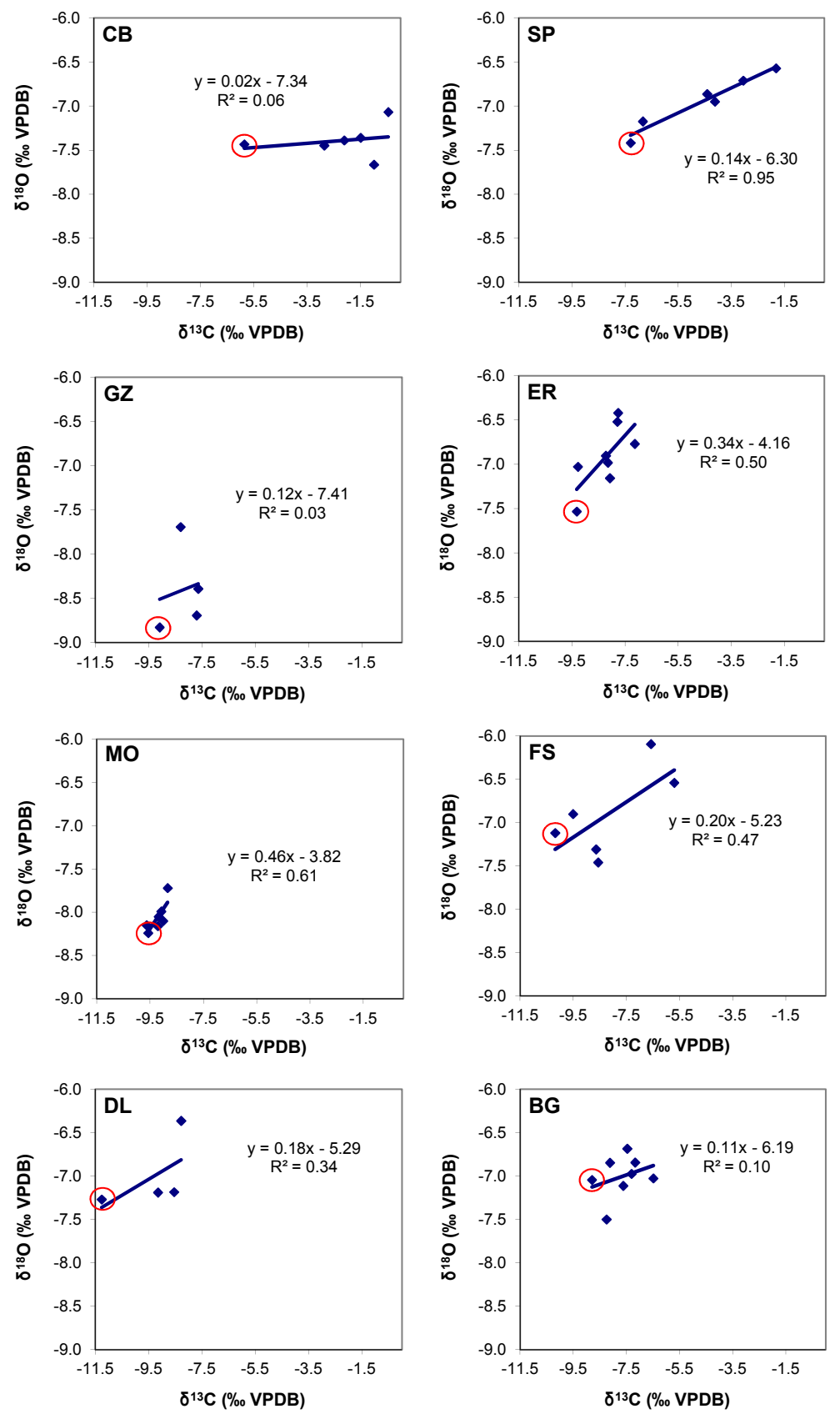

Fig. 5. Cross-plots of $\delta^{13} \mathrm{C}$ and $\delta^{18} \mathrm{O}$ for recent calcite precipitates from the studied cave sites. The plots show the extent of in-cave variability between samples caused by physical factors (e.g. drip rate, drip height, cave ventilation) and subsequent kinetic fractionation. Red circles indicate the least modified sample from each cave (using both its $\delta^{13} \mathrm{C}$ and $\delta^{18} \mathrm{O}$ ), chosen to demonstrate principles in the discussion part of this paper (Sect. 6).

including organic molecules (Frisia et al., 2000; Borsato et al., 2007a; Frisia and Borsato, 2010). It stands to reason that intense seasonal degassing does not favour columnar calcite growth, which was actually found where there is a high cave air $p \mathrm{CO}_{2}$, thus reducing the $p \mathrm{CO}_{2}$ difference between the dripwater and the cave atmosphere. These observations indicate that columnar fabrics are most likely found at low altitudes (see Fig. 2). The columnar fabric does not necessarily infer that speleothems are in isotopic equilibrium, instead, it reflects quasi-constant deposition with respect to the difference between predicted and measured water-calcite fractionation. This means that while the water-calcite oxygen isotope fractionation is unaffected by degassing and thus 
"quasi-constant", degassing may still affect the water-calcite carbon isotope fractionation.

The dendritic fabric (Fig. 4d), is produced from small, irregular shaped crystals that are characterised by stepped and kinked faces (Fig. 4c). These develop under irregular drip rates, strongly fluctuating saturation states and presence of impurities. Experience from monitoring in the Trentino region has shown that this fabric is common at mid-altitudes (between 1000 and $1500 \mathrm{~m}$ a.s.l.) and in the shallow and nearentrance zones of caves (McDermott et al., 1999; Frisia et al., 2011). The variable precipitation environment results in different degrees of isotopic fractionation, which may potentially range from quasi-constant to large deviations from equilibrium caused by the changing precipitation and drip rates.

A trend is therefore apparent between altitude and saturation state (Fig. 2c), and how these can control petrography (Frisia et al., 2000; Frisia and Borsato, 2010). This causes columnar fabrics exhibiting a quasi-constant fractionation factor to form at low altitudes, and dendritic fabrics with fluctuating fractionation factors to develop at mid-altitudes. However, under certain circumstances, columnar fabrics can also be found at high and mid altitudes, such as stalagmite SP1 from the SP cave (Fig. 4b). In this case, a thick overburden with a slow, matrix-flow infiltration pathway causes a steady drip rate, a reasonably low but fairly constant saturation state, and low concentration of impurities in the water. This highlights that, with our current understanding, fabric can indicate the variability of the fractionation factor in a stalagmite, but not the absolute magnitude of kinetic effects in

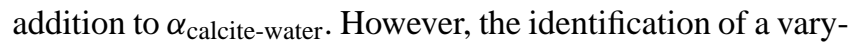
ing fractionation factor is important as it could complicate the interpretation of stable isotopes in a speleothem proxy record.

\subsection{Calcite-water oxygen isotope fractionation}

Successful reconstruction of palaeoclimate, from speleothems, relies on the calcite being formed at or close to equilibrium. This condition is often assumed since the high humidity cave environment is thought to aid equilibrium growth, and because there is little consensus over the definition of calcite equilibrium and its controlling factors. Speleothem data compiled from the literature spanning a wide range of latitudes and altitudes (see Supplement), in addition to the new data from this study (Table 2), are plotted as $1000 \ln \alpha$ against temperature (Fig. 6). A linear regression can be applied to this data to form an empirical speleothem line, also known as a "cave" line or $T$ function, where $T$ is temperature or transfer (McDermott et al., 2006; Tremaine et al., 2011; Fairchild and Baker, 2012). Although the compilation of data plots along a line, it does not represent speleothem calcite-water equilibrium, as indeed such equilibrium should create a non-linear fit (Fairchild and Baker, 2012). When equilibrium fractionation factors, calculated theoretically (Horita and Clayton, 2007; Chacko and Deines, 2008) and experimentally (Kim and O'Neil, 1997), are plotted alongside the observed data, there is a systematic offset of the speleothem line to higher $\delta^{18} \mathrm{O}$ values (higher $1000 \ln \alpha$ ) (Fig. 6). The nature of this offset is not well understood, but it has been proposed that it is not the result of kinetic fractionation since these should produce a wide range of enrichments, rather than a systematic offset (McDermott et al., 2006). For this reason, we analyse the distribution of the published speleothem data, and their relationship to the theoretical and experimental equilibrium fractionation lines.

The magnitude of oxygen isotope fractionation was calculated by comparing measured oxygen isotope data $\left(\delta^{18} \mathrm{O}_{\mathrm{c}}\right)$ with values predicted for equilibrium conditions $\left(\delta^{18} \mathrm{O}_{\mathrm{e}}\right)$. The difference between the measured and calculated oxygen isotope values $\left(\delta^{18} \mathrm{O}_{\mathrm{c}}-\delta^{18} \mathrm{O}_{\mathrm{e}}\right)$ depends on the selected equilibrium fractionation factor, and has variably been termed "offset" (Tremaine et al., 2011), $\Delta_{\text {dis }}$ (McDermott et al., 2011), and $\Delta^{18} \mathrm{O}_{\text {cc-e }}$ (Feng et al., 2012). Here, we adopt the term $\Delta_{\text {dis }}$ (McDermott et al., 2011). The estimated values were calculated, based on the measured dripwater isotope composition and cave temperature, using the various estimates (e.g. theoretical, experimental) of the fractionation factor $\left(\alpha_{\text {calcite-water }}\right)$ (Kim and O'Neil, 1997; Coplen, 2007; Horita and Clayton, 2007; Chacko and Deines, 2008). Initially, the $\Delta_{\text {dis }}$ was calculated for all the published speleothem data, presented in Fig. 6 and Supplement, using the speleothem $T$ function line, derived here, as an assumed equilibrium fractionation factor. The histogram frequency plot (Fig. 6, inset) shows the data distributed about the origin, with a mean of $0.0 \pm 0.6 \%$, and a tight normal distribution. A small tail is observed to more positive $\Delta_{\text {dis }}$ values, as a result of a few speleothem samples that experienced large deviations caused by in-cave disequilibrium isotope effects. A single value, from the Natural Bridge Caverns well shaft (3 August 2005) (Feng et al., 2012), displays an extremely negative $\Delta_{\text {dis }}$ that leaves it detached from the main group, and it is unclear as to the cause.

However, when the $\Delta_{\text {dis }}$ calculation is repeated with equilibrium fractionation factors from theoretical, experimental and previous field studies, the frequency distribution is similar, but its position relative to the origin shifts. If the fractionation factor calculated by Chacko and Deines (2008) were that of true equilibrium, then the majority of the speleothem samples would have $\delta^{18} \mathrm{O}_{c}$ values which are constantly more positive by over ca. $1 \%$, with the exception of the single value from the Natural Bridge Cavern that would be close to equilibrium. By using the fractionation factor predicted by Horita and Clayton (2007), a small proportion of speleothems lie close to equilibrium, but most exhibit values which are more positive by 0.5 to $1.25 \%$. The fractionation factor of Kim and O'Neil (1997) seems to best describe the natural cave calcite equilibrium precipitation, as most data reported in Fig. 6 are only 0.25 to $1 \%$ more 


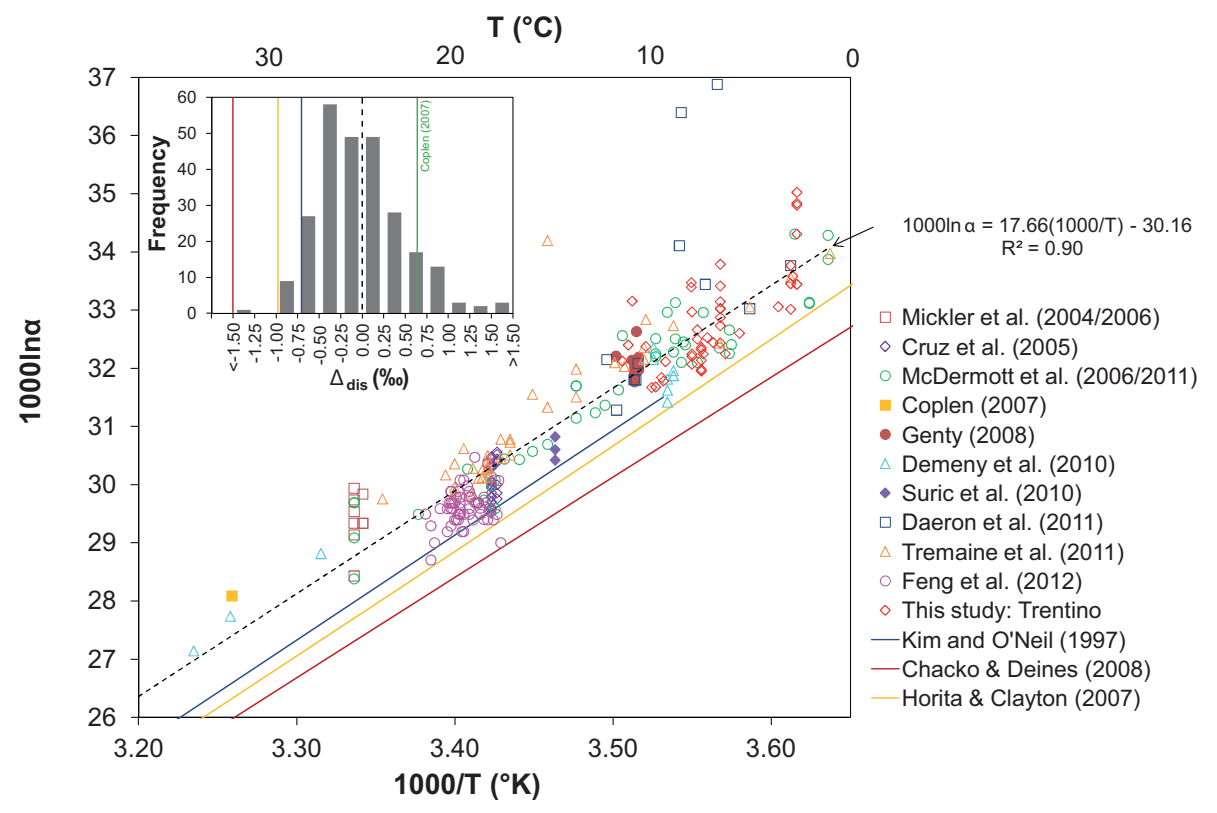

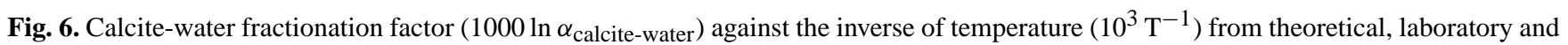
cave studies. Data from this study are plotted as red diamonds, other data points are derived from cave studies in the literature as noted in the legend and references therein (see Supplement). Solid lines are based on theoretical (Horita and Clayton, 2007; Chacko and Deines, 2008) and laboratory (Kim and O'Neil, 1997) studies. The dashed line is a linear best-fit of a compilation of all the cave calcite data giving $1000 \ln \alpha=17.66\left(10^{3} / \mathrm{T}\right)-30.16$. Note that in this compilation the term cave calcite includes hot water travertines of Demény et al. (2010), which although not shown here in the scale of the $1000 / \mathrm{T}$ axis (reaching as low as $2.94 \mathrm{~K}=67{ }^{\circ} \mathrm{C}$ ), they are included in the calculation of the best-fit line. Inset: frequency distribution of the magnitude of possible isotope disequilibrium effects of speleothem data in main figure $(N=259) . \Delta_{\text {dis }}$ has been evaluated as the difference between the calculated $\delta^{18} \mathrm{O}_{\mathrm{e}}$ and the measured $\delta^{18} \mathrm{O}_{\mathrm{c}}$, with a fractionation factor based on a linear function through all the speleothem data $\left(1000 \ln \alpha=17.66\left(10^{3} / \mathrm{T}\right)-30.16\right)$ giving a mean of $0.0 \pm 0.60(1 \sigma)$, shown by the dashed vertical line. Use of other fractionation factors results in similar frequency distributions but with a shift in mean $\Delta_{\text {dis }}$, which can be visualised by a shift in position of the origin. With the fractionation factor of Kim and O'Neil (1997) $\Delta_{\text {dis }}$ is shifted to a mean of $0.73 \pm 0.61$ (blue line), and using the Coplen (2007) equation, $\Delta_{\text {dis }}$ has a mean of $-0.65 \pm 0.60$ (green line). Using fractionation factors derived from theoretical studies and simplified by graphical linear interpolation, $\Delta_{\text {dis }}$ was found to average $0.98 \pm 0.60$ (Horita and Clayton, 2007) where $1000 \ln \alpha=18.117\left(10^{3} / \mathrm{T}\right)-32.721$ (yellow line), and $\Delta_{\text {dis }}$ was $1.5 \pm 0.60$ (Chacko and Deines, 2008) with $1000 \ln \alpha=17.231\left(10^{3} / \mathrm{T}\right)-30.183$ (red line).

positive relative to the theoretical values. Recently, however, numerous studies (e.g. Coplen, 2007; Dietzel et al., 2009; Gabitov et al., 2012) have questioned the reliability of the equilibrium fractionation factors of Kim and O'Neil (1997), and therefore, with the close correspondence to a majority of speleothem values, cast doubt on the equilibrium status of most speleothem calcite. Using the fractionation factor predicted by Coplen (2007), $\Delta_{\text {dis }}$ results in a considerably more positive value than the majority of speleothem samples. This would imply that the uptake of the lighter isotope of oxygen $\left({ }^{16} \mathrm{O}\right)$ into the faster growing calcites had occurred via the growth entrapment model (Watson, 2004; Dietzel et al., 2009; Gabitov et al., 2012). Given that Coplen (2007) used a very slow growing calcite speleothem, the first result from our compilation is that growth rate is indeed important in determining calcite oxygen isotope fractionation.

\subsection{Oxygen isotope fractionation with drip rate and temperature}

In the studied caves that exhibit a variety of drip rates ranging over several orders of magnitude, linear trends show an increase in the fractionation factor with decreasing drip rate (increasing drip interval; Fig. 7a). This trend is also apparent in $\Delta_{\text {dis }}$ (Fig. 7 b), showing a larger deviation from equilibrium with a slower drip rate (longer drip interval), where the equilibrium fractionation used for $\Delta_{\text {dis }}$ is that of Kim and O'Neil (1997), updated by Kim et al. (2007). Despite the good correlation observed in samples from the CB and SP, and also FS and BG caves, a direct relationship between fractionation factor and drip rate was not apparent in all caves monitored. This could be due to a limited range of measured drip rates. In addition, the individual caves are offset from each other and display different slope orientations. This indicates that although drip rate does play a role in the oxygen isotope fractionation, (i) it is not physically the drip rate that 
is controlling the fractionation but something linked to the time that each drop is exposed in the cave, causing the difference in slope, and (ii) there is another factor that is more critical than drip rate that is controlling fractionation, responsible for the offset in the absolute $1000 \ln \alpha$ values.

According to modelling studies (e.g. Deininger et al., 2012), the drip interval is linked to the reduction in the supersaturation during calcite precipitation, with a larger change in supersaturation occurring at the beginning of the drip interval as calcite precipitation commences. Therefore, there is a higher sensitivity at short drip intervals than long drip intervals. In a cave environment with ventilation (Spötl et al., 2005; Frisia et al., 2011), evaporation is also a major factor that must be considered (Day and Henderson, 2011; Deininger et al., 2012), and a longer drip interval would allow for an extended period of evaporation. In fact, the highest correlations between drip rate and fractionation are apparent in caves with the strongest ventilation, including the high altitude caves (CB and SP) and those with a large throughflow of water that enhance temperature related ventilation effects (BG and FS). High altitude caves are most likely to experience strong ventilation due to a thin soil cover and, consequently, higher frequency of open fissures and cracks in the rock, which allow passage of air into the cave chambers. A lower correlation was found between drip rate and $1000 \ln \alpha$ in samples from the ER cave that has ventilation (Frisia et al., 2011) but a closed entrance and relatively thick soil cover above the cave, which results in an air exchange time for the cave on the order of days (Frisia et al., 2011). This lapse of time is likely to be considerably longer than for the strongly ventilated (wind tube) caves such as BG.

The second factor, seen in the drip rate- $1000 \ln \alpha$ relationship shown in Fig. 7a, is the offset of cave trends with respect to each other. This is likely to be caused by the dependence of the fractionation factor on temperature (Figs. 7c and 6). Two explanations are proposed to account for the observed increase in fractionation factors with decreasing temperatures: (1) a decrease in the $\mathrm{SI}_{\mathrm{CC}}$ with increased elevation related to the shorter period when soil respiration is at its peak (warm season) and, thus, less soil $\mathrm{CO}_{2}$ production and less acidic infiltration waters; and (2) the calcite growth rate, which decreases when cave air temperature is cool (Mühlinghaus et al., 2009; Deininger et al., 2012). Lowering of the $\mathrm{SI}_{\mathrm{CC}}$ values with increased elevation has been observed in the studied dripwaters, which actually follow the decrease in cave air temperature (Fig. 2). Although calcite precipitation was not similarly monitored in all the caves considered in this study, there is a clear trend whereby calcite precipitation on glass slides was fastest at low altitude and slow at mid-altitude (Fig. 4, Sect. 5.3), while calcite growth at high altitudes is altogether scarce and if present is extremely slowly forming. It stands to reason that both the surface air temperature-related $\mathrm{SI}_{\mathrm{CC}}$ and the cave air temperature-related calcite growth rate explain the observed relationship between $1000 \ln \alpha$ and temperature in the study sites.
Over the range of altitudes and corresponding temperatures $\left(3-12{ }^{\circ} \mathrm{C}\right)$ considered here, however, the least modified examples from each cave, show a spread in values of only ca. $1 \%$ (Fig. 7d). Under isotopic equilibrium conditions, a difference of $2.16 \%$ would be expected over the $9{ }^{\circ} \mathrm{C}$ temperature gradient (O'Neil et al., 1969; Deininger et al., 2012). Since a lower than predicted offset is recorded, disequilibrium isotope fractionation must not be constant over the temperature gradient. The high altitude speleothems from caves CB and SP are greatly affected by drip rate variability (Fig. 7a), which influence evaporation during long drip intervals. The observed decreased difference in $\Delta_{\text {dis }}$ with elevation may, in part, be caused by enhanced ventilation and evaporation at altitude, which are also apparent in the large spread of data for each cave site (Fig. 7c,d). However, it is not just high altitude ventilation causing the apparent reduced $\Delta_{\text {dis. }}$. Processes occurring in the low altitude end-member caves have reduced oxygen isotope deviations from equilibrium, which further reduce the overall difference over the elevation gradient. The DL cave exhibits lower that predicted fractionation factors $(1000 \ln \alpha)$ despite the warm temperature (Fig. 7c). This can be explained as sporadic periods of cave passage blockage with either water or sand that lead to the cave chambers increasing in $\mathrm{CO}_{2}$ concentration. The enhanced cave air $p \mathrm{CO}_{2}$ reduces the gradient between dripwater $p \mathrm{CO}_{2}$ and that of the cave atmosphere, reducing the rate and absolute amount of $\mathrm{CO}_{2}$ degassing as the drip enters the cave but also importantly reducing the rate of calcite precipitation. This slower calcite precipitation rate leads to speleothem calcite that is closer to equilibrium than expected for the temperature of deposition in the cave environment. As the high temperature end-member of the $\Delta_{\text {dis }}$ trend (Fig. $7 d$ ), this explains the further reduction from the predicted value of 2.16 to ca. $1 \%$ of the oxygen isotope disequilibrium observed over the $9{ }^{\circ} \mathrm{C}$ temperature gradient.

\subsection{Orographic effects on oxygen isotopes variability}

Oxygen and hydrogen isotopes of cave dripwater decrease with altitude, but with a steeper gradient in the Adige Valley (Fig. 3). A similar pattern is seen in the annual weightedmean rainfall (Fig. 8), but with an offset to more ${ }^{18} \mathrm{O}$ enriched values. The wider, $\mathrm{N}-\mathrm{S}$ trending Adige Valley is predominantly influenced by Mediterranean air masses, except in winter months when the prevailing wind is northerly (Bertò et al., 2005). Having crossed the flat, low lying Po Plain, the Mediterranean air masses are orographically uplifted as they reach the mountains surrounding the Adige Valley (Longinelli and Selmo, 2003). As the air rises and cools, the heavier isotope is preferentially precipitated, resulting in rainwater exhibiting more negative $\delta^{18} \mathrm{O}$ with altitude (Bowen and Wilkinson, 2002). The same Mediterranean air masses affect the Valsugana Valley (Bertò et al., 2005). However, since this valley is narrow, E-W oriented and bounded by high mountains (between 2300 and $1900 \mathrm{~m}$ a.s.l.) 

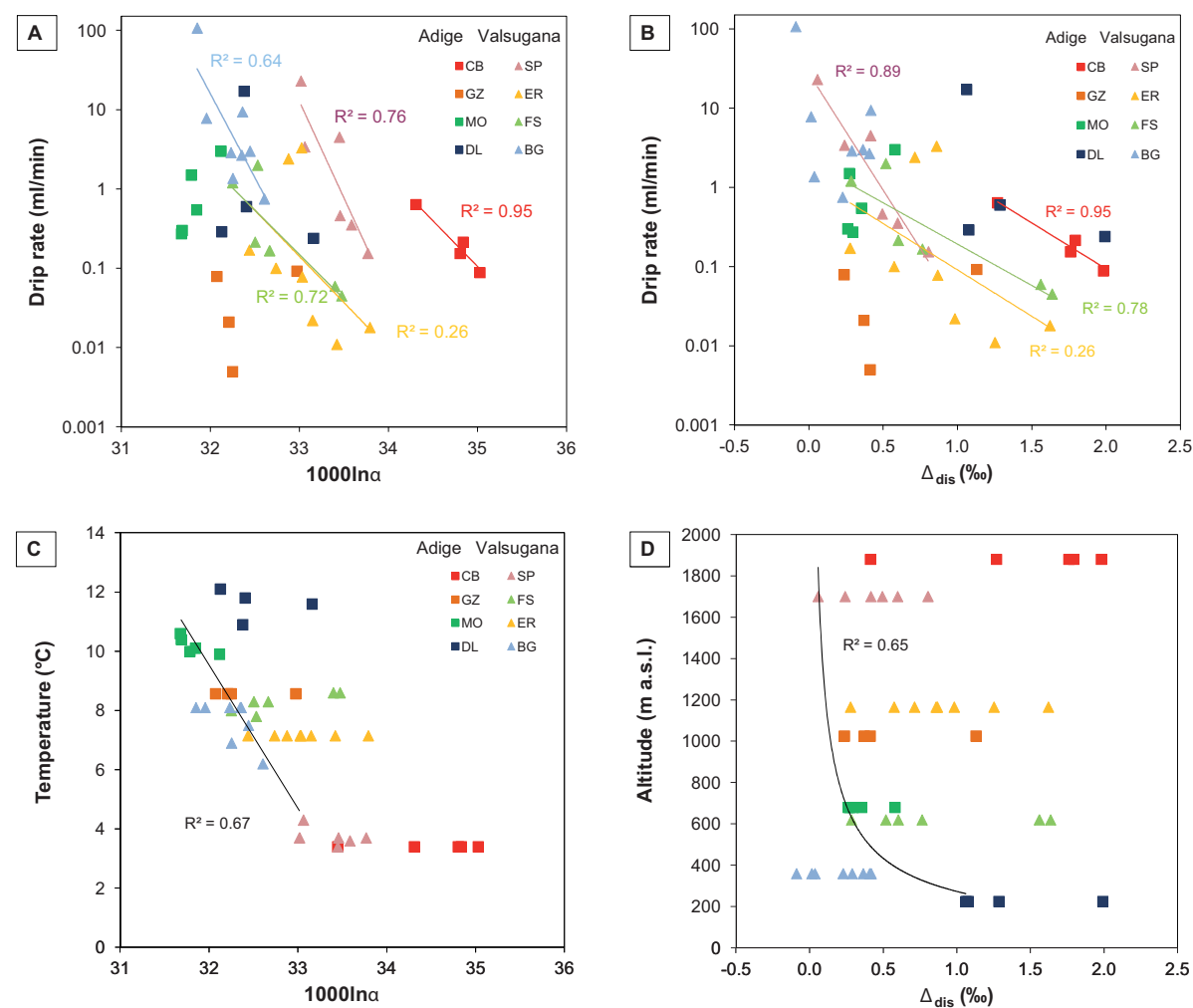

Fig. 7. Calcite-water fractionation factors and $\Delta_{\text {dis }}$ as a function of drip rate, temperature and altitude for the caves of Trentino. (A) Fractionation factor and (B) $\Delta_{\text {dis }}$ as a function of drip rate. Caves with drip rates extending several orders of magnitude exhibit exponential relationships (note log scale), indicating faster drip rates reduce the fractionation factor and the magnitude of possible isotope disequilibrium effects $\left(\Delta_{\text {dis }}\right)$. However, there is no trend in the dataset as a whole and a few of the caves exhibit no significant trend, but this may be due to the limited dataset or to site specific factors. (C) Fractionation factors plotted against the cave temperature. A linear relationship $\left(R^{2}=0.67\right)$ is exhibited for the least modified samples from each cave, excluding the CB cave, where the least modified calcite has no counterpart dripwater. (D) $\Delta_{\text {dis }}$ is plotted as a function of altitude as a more independent assessment than temperature, since the calculation of $\Delta_{\text {dis }}$ contains $\delta^{18} \mathrm{O}_{\mathrm{e}}$ that accounts for temperature within the equation of Kim and O'Neil (1997).
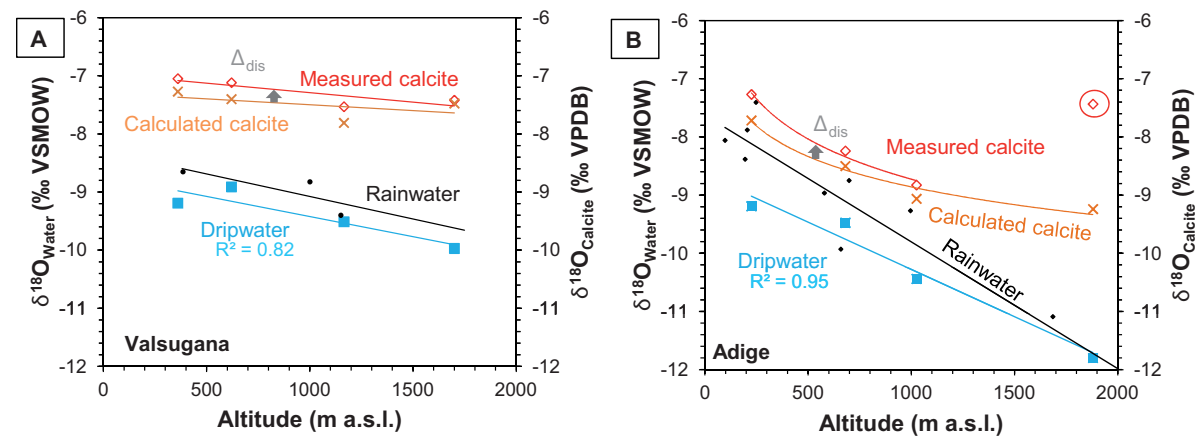

Fig. 8. Oxygen isotope values of the (A) Valsugana and (B) Adige Valleys plotted against altitude. Annual weighted-average rainwater values are shown in black dots (Bertò et al., 2005), cave dripwaters (solid blue squares) and corresponding calculated (Kim and O’Neil, 1997; updated by Kim et al., 2007) and measured calcite precipitates (orange crosses and red open diamonds, respectively). The calcite points plotted represent only one sample from each cave that we consider to be the least modified (see Fig. 5). This plot, therefore, serves to explain the relatively un-kinetically modified processes occurring in the cave and not to show an exhaustive range of possible $\delta^{18} \mathrm{O}$ values. The DL cave calculated calcite has been computed based on long-term monitoring of the cave dripwater, rather than a one-off sample, using the $\delta^{18} \mathrm{O}$ value of $-8.31 \pm 0.23 \%$ o. One outlier has been identified in the measured calcite data of $(\mathbf{B})$, that of the CB cave (1880 m). Note that waters are plotted on the VSMOW scale and calcite plotted against VPDB, and therefore values are not directly comparable. 
the moisture-laden air first encounters the mountain barrier leading to the high Asiago Plateau. Before entering the valley, the air is forced upwards, and rain-out occurs steadily depleting the moisture-laden vapour through Rayleigh fractionation. As the moisture reaches the long $(\mathrm{E}-\mathrm{W})$ crest of the plateau, the rain that falls at both high and low altitudes in the valley exhibits similar isotopic compositions (Fig. 8a) as there is not much difference in the source.

In Valsugana Valley caves (Fig. 8a), dripwater $\delta^{18} \mathrm{O}_{\mathrm{w}}$ is slightly depleted with respect to that of the annual weightedaverage rainwater value (Bertò et al., 2005) most likely because there is a lower evapotranspiration rate between autumn and spring. Most of the infiltration occurs during the cool seasons (including winter snowmelt), and therefore, there is a higher proportion of isotopically lighter autumn-winter season water, known as the "weighting effect" (Wackerbarth et al., 2010, 2012). The catchments of the low altitude caves are exposed to the north, keeping them shaded, while the SP cave opens on the high plateau, overlain by sunny meadows. This causes a relatively constant evapotranspiration rate (i.e. warm low altitudes are shaded, whereas cool high altitudes are sunny), and thus weighting effect, over the entire altitudinal gradient. The overall slope of the rainwater $\left(\Delta \delta^{18} \mathrm{O} / 100 \mathrm{~m}=-0.08 \%\right.$ ) and dripwater $\delta^{18} \mathrm{O}_{\mathrm{w}}$ (offset by a constant weighting effect) trends are rather gentle, caused by the E-W orientation of the Valsugana Valley. The gentle trend in meteoric $\delta^{18} \mathrm{O}_{\mathrm{w}}$ composition is counterbalanced by the differential temperature dependent calcite-water fractionation, resulting in the theoretical $\delta^{18} \mathrm{O}_{\mathrm{e}}$ value for calcite (Kim and O'Neil, 1997) anywhere in the Valsugana Valley, independent of altitude, being $-7.7 \pm 0.2 \%$ o (Fig. 8a). The geomorphological setting and rainfall trajectories predominantly from the Mediterranean, thus, combine to render caves of the Valsugana Valley unsuitable for the reconstruction of robust, absolute palaeotemperature changes using only speleothem oxygen isotope ratio values. Past trajectory changes, however, can still be reconstructed (e.g. Scholz et al., 2012). The quasi-constant predicted calcite $\delta^{18} \mathrm{O}_{\mathrm{e}}$ value with altitude was measured in the speleothem calcite as a slightly decreasing trend with elevation. This decreasing speleothem calcite $\delta^{18} \mathrm{O}_{\mathrm{c}}$ could be wrongly taken as a signal of the rainwater $\delta^{18} \mathrm{O}_{\mathrm{w}}$. As seen previously (Fig. 7), it is caused by enhanced deviation from isotopic equilibrium at low altitudes due to more rapid calcite precipitation rates and strong ventilation at the BG cave, which enrich these low altitude Valsugana Valley cave sites away from the predicted equilibrium values.

In the Adige Valley (Fig. 8b), the meteoric $\delta^{18} \mathrm{O}_{\mathrm{w}}$ trend follows a steeper $\left(\Delta \delta^{18} \mathrm{O} / 100 \mathrm{~m}=-0.22 \%\right)$ and more typical slope, with altitude. The cave dripwaters exhibit more negative values due to autumn and (winter) spring infiltration via the weighting effect. However, the cave dripwater values do not plot parallel to the rainwater, but converges with the rainwater slope at high altitude. At high altitude the full season of rainwater contributes to infiltration, whereas at warmer low altitude only the cooler seasons contribute, since most of the summer precipitation is lost through evapotranspiration (i.e. the weighting effect). At the warm, low altitude cave site (DL), the difference between the rainfall and cave dripwater measured here was around $1 \%$. Therefore, this weighting effect needs to be more carefully accounted for in cave monitoring studies so that it can be effectively included and tested for in oxygen isotope enabled, rainwaterforced, dripwater-stalagmite models (e.g. Wackerbarth et al., 2012), particularly where cave sites of varying altitudes and latitudes are modelled together.

The calculated calcite $\delta^{18} \mathrm{O}_{\mathrm{e}}$ of the Adige Valley exhibits a non-linear trend due to the strong influence of temperature on the water isotopes and the cave air. The measured cave calcite $\delta^{18} \mathrm{O}_{c}$ exhibits a similar trend to that calculated but with a deviation to slightly higher values at low altitudes due to the greater deviation from equilibrium (Fig. 7). Overall, at these well-chosen sites, the change in oxygen isotopes measured in cave calcite over the altitude range of the Adige Valley exceeds the minimal modifications by disequilibrium isotopic effects. Therefore, at well-chosen drip sites, changes in temperature associated with climate variability should be recognisable, and possibly quantifiable, in the $\delta^{18} \mathrm{O}$ speleothem record.

However, one outlier $\mathrm{CB}$ cave $\delta^{18} \mathrm{O}_{\mathrm{c}}$ has a higher value than expected for its altitude. This is possibly due to strong modification of this sample by disequilibrium effects. In particular, ventilation and evaporation have been identified as causing large modifications (possibly several per mill) to the calcite oxygen isotope ratio during long drip intervals (Deininger et al., 2012). Interestingly, the only seemingly active speleothem growth in the CB cave appeared within a constriction of the passageway where the ventilation rate would be enhanced, increasing evaporation that may provide a mechanism for reaching supersaturation and thus allowing calcite precipitation at this high altitude site. An alternative reason for the enriched $\mathrm{CB}$ cave calcite could be that the slow precipitation rate caused sampling to remove a considerable number of years growth, including large inter-annual variability in meteoric oxygen isotope composition.

\subsection{Carbon isotopes of speleothem calcite}

Cave calcite carbon isotopes exhibit a strong pattern towards more positive values with increasing altitude (Fig. 9a). Recent studies have shown that the proportions of plants with different photosynthetic pathways $\left(\mathrm{C}_{3}\right.$ and $\left.\mathrm{C}_{4}\right)$ above the cave do not affect the $\delta^{13} \mathrm{C}$ of the cave air (Breecker et al., 2012). In addition, the trend in Fig. 9a considers only the least modified samples from each cave, and therefore isotope fractionation effects are minimised and are not responsible for the relationship with altitude. A modelled increase in temperature has been shown to result in generally higher calcite $\delta^{13} \mathrm{C}$ values (Mühlinghaus et al., 2009), which is opposite to the observed altitudinal trend in the speleothem $\delta^{13} \mathrm{C}$ data 

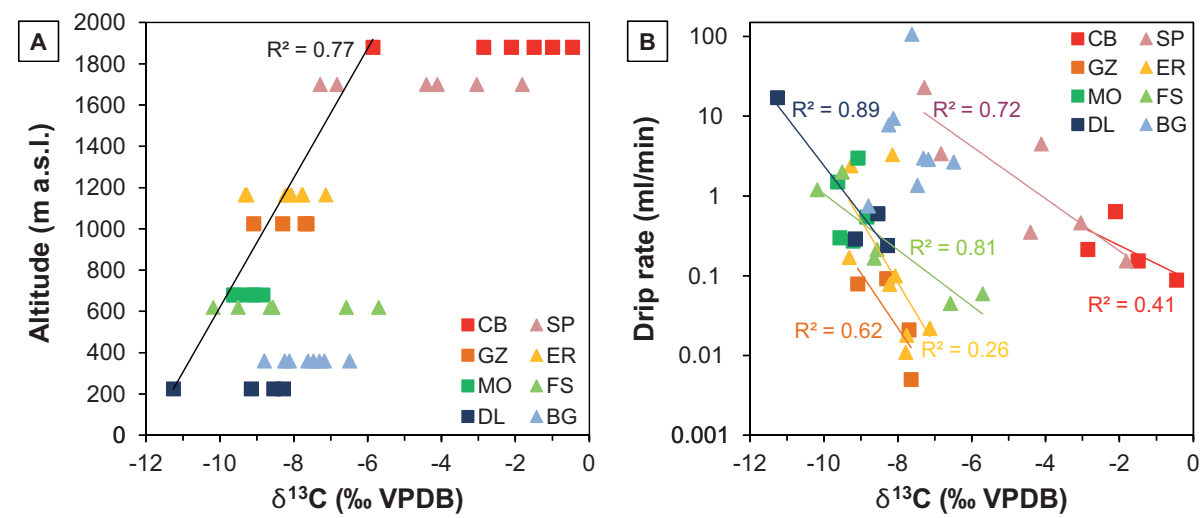

Fig. 9. Calcite carbon isotope values against (A) the altitude of the cave entrance and (B) drip rate. In (A), the trend lines have been calculated using just the least modified calcite precipitates from each cave site (see Fig. 5). In (B), exponential trends (note log scale) are shown for individual cave sites.

(Fig. 9a). More negative calcite $\delta^{13} \mathrm{C}$ values in the warmer caves at low altitude are likely to be related to the vegetation cover (thick deciduous forest), the abundant litter produced by autumnal vegetation die back, thicker soil and a longer vegetative season (thus soil respiration) relative to the high elevation caves. All these factors combine to imprint the infiltration waters with a strongly negative (light), biogenic $\delta^{13} \mathrm{C}$ signal. By contrast, at high altitudes, the $\delta^{13} \mathrm{C}$ signal is closer to atmospheric values. Fohlmeister et al. (2011) modelled a decrease in the DIC $\delta^{13} \mathrm{C}$ with increasing soil air $p \mathrm{CO}_{2}$. In our study, cave air $p \mathrm{CO}_{2}$ is shown to be higher at low altitudes as a result of enhanced soil respiration, which is in agreement with the model (Fohlmeister et al., 2011) and should account for a large part of the $\delta^{13} \mathrm{C}$ increase with elevation gain.

Individual cave carbonates also exhibit a spread of $\delta^{13} \mathrm{C}$ values (Fig. 9a) that correlate with the drip rate (Fig. 9b). This can be partly attributed to the longer drip intervals (slower drip rate) allowing a greater time for bicarbonate concentration to decrease in the solution, leading to higher calcite $\delta^{13} \mathrm{C}$ values (Mühlinghaus et al., 2009). However, a second process must be occurring, as the longest drip intervals were measured at the GZ cave, but these exhibited only minor enrichments in calcite $\delta^{13} \mathrm{C}$ values (Fig. 9). At the GZ cave site, speleothems are forming in a small chamber where ventilation is highly restricted. It is, thus, likely that ventilation is the process which further enriches calcite ${ }^{13} \mathrm{C}$ (cf. Deininger et al., 2012), occurring in those caves where seasonal contrast and the morphology of the cave passages, as well as the presence of fractures, allows greater air exchange than at the $\mathrm{GZ}$ cave. Up to $6 \%{ }^{13} \mathrm{C}$ enrichment is observed in calcite from individual caves monitored during this study (Fig. 9), with this representing a minimum spread of values, since it assumes that the least modified sample baseline does not suffer from deviation associated to ventilation effects.
In the case of the BG cave, it is clear that all the samples taken in the cave deviate from the entrance altitudinal trend by approximately $+2 \%$. This, in part, can be attributed to the higher infiltration elevation (ca. $900 \mathrm{~m}$ a.s.l.), where different proportions of soil gas and dissolved bedrock result in higher $\delta^{13} \mathrm{C}$ values. It is not, however, a direct effect of the cooler temperature of the higher infiltration elevation water, as a decrease in temperature alone would cause a negative shift in calcite $\delta^{13} \mathrm{C}$ values (Mühlinghaus et al., 2009). Some of the $\mathrm{BG}$ cave values are then modified further by strong ventilation, caused by flowing water and large seasonal temperature contrasts, causing enhanced ventilation driven degassing and evaporation that increase their calcite $\delta^{13} \mathrm{C}$ values. The two highest altitude caves show the largest isotope fractionation effects and, along with BG, are highly ventilated. A period of strong ventilation during winter 2001-2002 was correlated with particularly high dripwater $\delta^{13} \mathrm{C}$ values in the Obir cave (Spötl et al., 2005), indicating the importance of ventilation and evaporation on the carbon isotopes in other studies (Frisia et al., 2011).

\subsection{Implications for speleothem-based palaeoclimate studies}

In this study, caves distributed along a steep altitudinal gradient have been used to emulate the temperature change observed over large-amplitude climate events. Deviation from equilibrium of the oxygen isotope signal poses a problem for robust palaeotemperature reconstructions (Mickler et al., 2006). However, there is still a great deal of uncertainty about the position of calcite-water equilibrium and the factors controlling it in the cave environment, under both sub-aqueous and sub-aerial conditions (Kim and O'Neil, 1997; Coplen, 2007; Chacko and Deines, 2008; Day and Henderson, 2011; Gabitov et al., 2012). Ranges in stable isotope values observed at an individual cave site, and therefore attributed to in-cave fractionation processes rather than wider-scale 
environmental conditions (e.g. temperature, vegetation etc.), reach $1.5 \%$ in oxygen (Fig. 7) and up to $6 \%$ in carbon isotopes (Fig. 9), with the largest modifications occurring in the caves with strongest ventilation. This isotopic fractionation can potentially obscure a temperature signal or information on the original composition of the dripwater. However, when combined with petrography and other proxies, it may provide alternative environmental information, such as the effects of ventilation.

Of interest here, however, is what will happen in terms of isotopic fractionation over a large-amplitude climate change that would affect air temperature, vegetation, soil quality and thus $p \mathrm{CO}_{2}$ and dripwater calcite supersaturation. The altitudinal gradient studied here can be used to infer the temperature and associated vegetation and soil changes that occur over high amplitude temperature changes, such as over glacial-interglacial transitions. During a warm interstadial (represented here by the low altitude caves), the rate of calcite precipitation would be high, which results in oxygen isotope enrichment during precipitation (Scholz et al., 2009). This should lead to a lower fractionation factor (1000 $\left.\ln \alpha_{\text {calcite-water }}\right)$ and more positive $\delta^{18} \mathrm{O}$ values. In the absence of water stress, a thick and mature soil, supporting deciduous forest with efficient, warm season soil respiration, would yield a high soil $p \mathrm{CO}_{2}$ concentration and a negative biogenic $\delta^{13} \mathrm{C}$ signal of the DIC, which is transferred to the cave and encapsulated as negative calcite $\delta^{13} \mathrm{C}$. In addition, the thick soil cover would abate ventilation by restricting air flow through fissures and fractures at the surface, which maintains a depleted ${ }^{13} \mathrm{C}$ isotope signal in the dripwater and speleothem calcite.

By contrast, in a cold or glacial setting (the high altitude cave proxy), a slow rate of speleothem calcite precipitation would lead to higher fractionation factors (1000 $\left.\ln \alpha_{\text {calcite-water }}\right)$ and lower $\delta^{18} \mathrm{O}$ values. The lower $\Delta_{\text {dis }}$ calculated (Fig. 7) should mean that these high altitude, slowly growing samples are forming closer to equilibrium, but the concept of equilibrium is elusive and our calculation relies on uncertain experimental values (Coplen, 2007; Gabitov et al., 2012). At lower growth rates, and in association with long drip intervals, there is a possibility of the isotope data being overprinted by the cave atmosphere (Dreybrodt and Scholz, 2011), this is found to be a particular problem when there is strong ventilation in the cave. During a colder period, the vegetation dies back and the soil reduces in quality and thickness or can sometimes be removed completely or substantially by advancing glaciers or strong winds. This allows stronger cave ventilation as air circulates through fractures now exposed at the surface. Carbon isotope values are higher due to the lower soil $p \mathrm{CO}_{2}$ concentrations, but then further enriched in ${ }^{13} \mathrm{C}$ due to higher in-cave ventilation driven degassing and evaporation.

Day and Henderson (2011) concluded that cold caves with a fast drip rate are the most ideal sites for palaeoclimate reconstruction from speleothems. Our data support their claim, and show that a high calcite precipitation rate, often found in warm caves, can enhance deviations from equilibrium and thus colder caves would be more appropriate sites for palaeoclimate research. In addition, a fast drip rate, in many cases, reduces the amount of in-cave overprinting by the cave atmosphere (Dreybrodt and Scholz, 2011), which is particularly related to strong ventilation and evaporation of the speleothem-forming solution (Day and Henderson, 2011; Deininger et al., 2012). However, we also observed that each cave has unique processes, and even a small amount of cave sampling (such as in this study) can reveal important information about the cave processes, and whether the cave responds similarly to that expected by the models and experiments. For example, in the GZ cave, despite the very long drip intervals, there appeared to be little overprinting by the cave atmosphere due to the minimal ventilation in the cave chamber. Furthermore, the highest-temperature cave studied, the DL cave, appears to have a reduced calcite precipitation rate due to higher cave air $p \mathrm{CO}_{2}$ following periods of cave blockage and reduced ventilation, leading to build-up of $\mathrm{CO}_{2}$. These two examples from eight monitored caves highlight that although modelling and cave analogue laboratory experiments are highly useful in understanding processes in the cave environment, they are no substitute to cave monitoring.

We end the discussion by looking at the effects that the in-cave disequilibrium fractionation would have on a typical speleothem stable isotope proxy record, focusing on the significant effects of ventilation and evaporation found in this study. For the Northern Italy region, and likely much of continental Europe, a decrease in temperature would result in more negative $\delta^{18} \mathrm{O}$ of infiltrating water, which would be transferred to the calcite, and less negative calcite $\delta^{13} \mathrm{C}$ values. As previously discussed, a cooler climate would lead to stronger ventilation via a reduction in soil cover and possibly slower drip rates, which would increase both the calcite $\delta^{18} \mathrm{O}$ and $\delta^{13} \mathrm{C}$ values. For $\delta^{18} \mathrm{O}$ this in-cave effect works in the opposite direction to the climate signal and may complicate interpretation or even mask the environmental signal. However, source water provenance and trajectory, and its interaction with topography will have a dominant effect on the oxygen isotopes, in addition to seasonality of the rainfall at the site. Conversely, for the $\delta^{13} \mathrm{C}$ signal, the ventilation and associated kinetic disequilibrium effects form a positive reinforcement that amplifies the original $\delta^{13} \mathrm{C}$ climate signal. This may explain why under certain circumstances the $\delta^{13} \mathrm{C}$ signal has been more successfully interpreted than that of oxygen during climate transitions in Europe (e.g. Genty et al., 2003; Hodge et al., 2008; Scholz et al., 2012). This interpretation, however, does not cover all karst regions where, for example, for climatic reasons ventilation may correspond to warmer or wetter periods or where the source water has a different provenance and trajectory. 


\section{Conclusions}

Using a steep altitudinal gradient, we have demonstrated that temperature does indeed have a strong influence on the isotopic fractionation between water and speleothem calcite. Over the $9^{\circ} \mathrm{C}$ temperature gradient observed in our dataset, higher temperatures account for an approximate $1 \%$ o (ca. 1.5 units of $1000 \ln \alpha$ ) increase in $\delta^{18} \mathrm{O}_{\mathrm{c}}$ values and $5 \%$ decrease in $\delta^{13} \mathrm{C}$ values of calcite. Whereas drip rate and its associated kinetic effects have been shown to be responsible for modifying $\delta^{18} \mathrm{O}_{\mathrm{c}}$ up to $1.5 \%$ o ( $<2$ units of $1000 \ln \alpha$ ) and calcite $\delta^{13} \mathrm{C}$ by $<6 \%$, within an individual cave. The primary driving forces for the oxygen isotopic changes are temperature-related calcite supersaturation and calcite growth rate, whereas carbon isotopes are affected by the temperature-related biogenic $\delta^{13} \mathrm{C}$ signal of the soil, $p \mathrm{CO}_{2}$ concentration and the drip interval.

Data presented in this study are in strong agreement with the current views from models and cave analogue experiments (Mühlinghaus et al., 2009; Polag et al., 2010; Day and Henderson, 2011; Dreybrodt and Scholz, 2011). Most significant is the relative importance of ventilation and evaporation in combination with the drip interval (Day and Henderson, 2011; Deininger et al., 2012). Speleothem calcite from dynamically ventilated caves, often exhibited significant deviations from equilibrium, increasing both $\delta^{13} \mathrm{C}$ and $\delta^{18} \mathrm{O}$. Stronger ventilation is expected under colder climates, such as during glacial periods. Therefore, speleothem records may be affected by significant shifts in stable isotope values, caused by in-cave kinetic disequilibrium effects, as they pass over glacial-interglacial transitions.

\section{Supplementary material related to this article is available online at: http://www.clim-past.net/9/99/2013/ cp-9-99-2013-supplement.pdf.}

Acknowledgements. This work has been carried out within the INTCLIM project co-funded by the European Commission under the 7th Framework Programme Marie Curie Actions Scheme and the Autonomous Province of Trento (PAT). For cave access, we would like to thank the Gruppo Grotte Selva di Grigno (BG Cave) and Gruppo Grotte Trevisol-CAI Vicenza (SP Cave). We appreciate the laboratory help of M. Wimmer (Innsbruck) and N. Angeli (SEM, Trento) and field support of M. Zandonati (Trento). We are grateful to guest editor A. Mangini and reviewers D. Scholz and D. Tremaine for constructive criticisms of the original manuscript.

Edited by: A. Mangini

\section{References}

Baldini, J. U. L., McDermott, F., and Fairchild, I. J.: Spatial variability in cave drip water hydrochemistry: Implications for stalagmite paleoclimate records, Chem. Geol., 235, 390-404, 2006.

Bar-Matthews, M., Ayalon, A., Gilmour, M., Matthews, A., and Hawkesworth, C. J.: Sea-land oxygen isotopic relationships from planktonic foraminifera and speleothems in the Eastern Mediterranean region and their implication for paleorainfall during interglacial intervals, Geochim. Cosmochim. Acta, 67, 3181-3199, 2003.

Bertò, A., Borsato, A., Frisia, S., Miorandi, R., and Zardi, D., Monthly isotopic signal of the precipitated water in the Province of Trento: Lagrangian analysis and discussion of measurements, in: 28th International Conference on Alpine Meteorology, Croatian Meteorological Journal, Zadar, Croatia, 432-435, 2005.

Borsato, A., Frisia, S., and Sartorio, D.: Late Triassic-Early Liassic evolution at the margin between the Trento Platform and the Lombardy Basin (Brenta Dolomites, Italy), Studi Trentini di Scienze Naturali, Acta Geologia, 69, 5-35, 1994.

Borsato, A., Frisia, S., Fairchild, I. J., Somogyi, A., and Susini, J.: Trace element distribution in annual stalagmite laminae mapped by micrometer-resolution X-ray fluorescence: Implications for incorporation of environmentally significant species, Geochim. Cosmochim. Acta, 71, 1494-1512, 2007a.

Borsato, A., Miorandi, R., Corradini, F., and Frisia, S.: Idrochimica delle acque ipogee in Trentino: specie, variabilità stagione, gradiente altitudinale e implicazioni per gli studi climaticoambientali da speleotemi, Studi Trent. Sci. Nat., Acta Geol., 82, 123-150, 2007b.

Bowen, G. J. and Wilkinson, B.: Spatial distribution of $\delta^{18} \mathrm{O}$ in meteoric precipitation, Geology, 30, 315-318, 2002.

Breecker, D. O., Payne, A. E., Quade, J., Banner, J. L., Ball, C. E., Meyer, K. W., and Cowan, B. D.: The sources and sinks of $\mathrm{CO}_{2}$ in caves under mixed woodland and grassland vegetation, Geochim. Cosmochim. Acta, 96, 230-246, 2012.

Chacko, T. and Deines, P.: Theoretical calculation of oxygen isotope fractionation factors in carbonate systems, Geochim. Cosmochim. Acta, 72, 3642-3660, 2008.

Cheng, H., Edwards, R. L., Broecker, W. S., Denton, G. H., Kong, X. G., Wang, Y. J., Zhang, R., and Wang, X. F.: Ice Age Terminations, Science, 326, 248-252, 2009.

Coplen, T. B.: Calibration of the calcite-water oxygen-isotope geothermometer at Devils Hole, Nevada, a natural laboratory, Geochim. Cosmochim. Acta, 71, 3948-3957, 2007.

Craig, H.: Isotopic Variations in Meteoric Waters, Science, 133, 1702, doi:10.1126/science.133.3465.1702, 1961.

Cruz, F. W., Burns, S. J., Karmann, I., Sharp, W. D., Vuille, M., Cardoso, A. O., Ferrari, J. A., Dias, P. L. S., and Viana, O.: Insolation-driven changes in atmospheric circulation over the past 116,000 years in subtropical Brazil, Nature, 434, 63-66, 2005.

Daëron, M., Guo, W., Eiler, J., Genty, D., Blamart, D., Boch, R., Drysdale, R., Maire, R., Wainer, K., and Zanchetta, G.: ${ }^{13} \mathrm{C}^{18} \mathrm{O}$ clumping in speleothems: Observations from natural caves and precipitation experiments, Geochim. Cosmochim. Acta, 75, 3303-3317, 2011.

Day, C. C. and Henderson, G. M.: Oxygen isotopes in calcite grown under cave-analogue conditions, Geochim. Cosmochim. Acta, 75, 3956-3972, 2011. 
Deininger, M., Fohlmeister, J., Scholz, D., and Mangini, A.: Isotope disequilibrium effects: The influence of evaporation and ventilation effects on the carbon and oxygen isotope composition of speleothems - A model approach, Geochim. Cosmochim. Acta, 96, 57-79, 2012.

Demény, A., Kele, S., and Siklòsy, Z.: Empirical equations for the temperature dependence of calcite-water oxygen isotope fractionation from 10 to $70^{\circ} \mathrm{C}$, Rapid Commun. Mass Sp., 24, 35213526, 2010.

Dietzel, M., Tang, J., Leis, A., and Kohler, S. J.: Oxygen isotopic fractionation during inorganic calcite precipitation - Effects of temperature, precipitation rate and $\mathrm{pH}$, Chem. Geol., 268, 107$115,2009$.

Dreybrodt, W.: Evolution of the isotopic composition of carbon and oxygen in a calcite precipitating $\mathrm{H}_{2} \mathrm{O}-\mathrm{CO}_{2}-\mathrm{CaCO}_{3}$ solution and the related isotopic composition of calcite in stalagmites, Geochim. Cosmochim. Acta, 72, 4712-4724, 2008.

Dreybrodt, W.: Comments on processes contributing to the isotope composition of ${ }^{13} \mathrm{C}$ and ${ }^{18} \mathrm{O}$ in calcite deposited to speleothems, Acta Carsologica, 40, 233-238, 2011.

Dreybrodt, W. and Scholz, D.: Climatic dependence of stable carbon and oxygen isotope signals recorded in speleothems: From soil water to speleothem calcite, Geochim. Cosmochim. Acta, 75, 734-752, 2011.

Drysdale, R. N., Hellstrom, J. C., Zanchetta, G., Fallick, A. E., Sánchez Goñi, M. F., Couchoud, I., McDonald, J., Maas, R., Lohmann, G., and Isola, I.: Evidence for Obliquity Forcing of Glacial Termination II, Science, 325, 1527-1531, 2009.

Fairchild, I. J. and Baker, A.: Speleothem science: from process to past environments, Wiley-Blackwell, 2012.

Fairchild, I. J., Borsato, A., Tooth, A. F., Frisia, S., Hawkesworth, C. J., Huang, Y. M., McDermott, F., and Spiro, B.: Controls on trace element $(\mathrm{Sr}-\mathrm{Mg}$ ) compositions of carbonate cave waters: implications for speleothem climatic records, Chem. Geol., 166, 255-269, 2000.

Feng, W., Banner, J. L., Guilfoyle, A. L., Musgrove, M., and James, E. W.: Oxygen isotopic fractionation between drip water and speleothem calcite: A 10-year monitoring study, central Texas, USA, Chem. Geol., 304-305, 53-67, 2012.

Fohlmeister, J., Scholz, D., Kromer, B., and Mangini, A.: Modelling carbon isotopes of carbonates in cave drip water, Geochim. Cosmochim. Acta, 75, 5219-5228, 2011.

Frisia, S. and Borsato, A.: Karst, in: Developments in Sedimentology, Carbonates in Continental Settings, edited by: AlonsoZarza, A. M. and Tanner, L. H., Elsevier, The Netherlands, 269318,2010

Frisia, S. and Wenk, H.-R.: TEM and AEM study of pervasive, multi-step dolomitization of the Upper Triassic Dolomia Principale (Northern Italy), J. Sediment. Petrol., 63, 1049-1058, doi:10.1306/D4267C94-2B26-11D7-8648000102C1865D, 1993.

Frisia, S., Borsato, A., Fairchild, I. J., and McDermott, F.: Calcite fabrics, growth mechanisms, and environments of formation in speleothems from the Italian Alps and southwestern Ireland, J. Sediment. Res., 70, 1183-1196, 2000.

Frisia, S., Borsato, A., Preto, N., and McDermott, F.: Late Holocene annual growth in three Alpine stalagmites records the influence of solar activity and the North Atlantic Oscillation on winter climate, Earth Planet. Sc. Lett., 216, 411-424, 2003.
Frisia, S., Fairchild, I. J., Fohlmeister, J., Miorandi, R., Spötl, C., and Borsato, A.: Carbon mass-balance modelling and carbon isotope exchange processes in dynamic caves, Geochim. Cosmochim. Acta, 75, 380-400, 2011.

Gabitov, R. I., Watson, E. B., and Sadekov, A.: Oxygen isotope fractionation between calcite and fluid as a function of growth rate and temperature: An in situ study, Chem. Geol., 306-307, 92$102,2012$.

Gat, J. R.: Oxygen and hydrogen isotopes in the hydrological cycle, Annu. Rev. Earth Pl. Sc., 24, 225-262, 1996.

Genty, D., Blamart, D., Ouahdi, R., Gilmour, M., Baker, A., Jouzel, J., and Van-Exter, S.: Precise dating of Dansgaard-Oeschger climate oscillations in western Europe from stalagmite data, Nature, 421, 833-837, 2003.

Hodge, E. J., Richards, D. A., Smart, P. L., Andreo, B., Hoffmann, D. L., Mattey, D. P., and González-Ramón, A.: Effective precipitation in southern Spain $(\sim 266$ to $46 \mathrm{ka})$ based on a speleothem stable carbon isotope record, Quaternary Res., 69, 447-457, 2008.

Horita, J. and Clayton, R. N.: Comment on the studies of oxygen isotope fractionation between calcium carbonates and water at low temperatures by Zhou and Zheng (2003; 2005), Geochim. Cosmochim. Acta, 71, 3131-3135, 2007.

Kim, S.-T. and O'Neil, J. R.: Equilibrium and nonequilibrium oxygen isotope effects in synthetic carbonates, Geochim. Cosmochim. Acta, 61, 3461-3475, 1997.

Kim, S.-T., Mucci, A., and Taylor, B. E.: Phosphoric acid fractionation factors for calcite and aragonite between 25 and $75^{\circ} \mathrm{C}$ : Revisited, Chem. Geol., 246, 135-146, 2007.

Lachniet, M. S.: Climatic and environmental controls on speleothem oxygen-isotope values, Quaternary Sci. Rev., 28, 412-432, 2009.

Longinelli, A. and Selmo, E.: Isotopic composition of precipitation in Italy: a first overall map, J. Hydrol., 270, 75-88, 2003.

Luetscher, M. and Jeannin, P.-Y.: Temperature distribution in karst systems: the role of air and water fluxes, Terra Nova, 16, 344350, 2004.

Mattey, D., Fairchild, I. J., Atkinson, T. C., Latin, J.-P., Ainsworth, M., and Durell, R.: Seasonal microclimate control of calcite fabrics, stable isotopes and trace elements in modern speleothem from St Michaels Cave, Gibraltar, in: Tufas and Speleothems: Unravelling the Microbial and Physical Controls, edited by: Pedley, H. M. and Rogerson, M., Geological Society, London, Special Publications, 323-344, 2010.

McDermott, F.: Palaeo-climate reconstruction from stable isotope variations in speleothems: a review, Quaternary Sci. Rev., 23, 901-918, 2004.

McDermott, F., Frisia, S., Huang, Y. M., Longinelli, A., Spiro, B., Heaton, T. H. E., Hawkesworth, C. J., Borsato, A., Keppens, E., Fairchild, I. J., van der Borg, K., Verheyden, S., and Selmo, E.: Holocene climate variability in Europe: Evidence from $\delta^{18} \mathrm{O}$, textural and extension-rate variations in three speleothems, Quaternary Sci. Rev., 18, 1021-1038, 1999.

McDermott, F., Schwarcz, H., and Rowe, P. J.: Isotopes in speleothems, in: Isotopes in Palaeoenvironmental Research, edited by: Leng, M. J., Springer, The Netherlands, 185-225, 2006. 
McDermott, F., Atkinson, T. C., Fairchild, I. J., Baldini, L. M., and Mattey, D. P.: A first evaluation of the spatial gradients in $\delta^{18} \mathrm{O}$ recorded by European Holocene speleothems, Global Planet. Change, 79, 275-287, 2011.

Mickler, P. J., Banner, J. L., Stern, L., Asmerom, Y., Edwards, R. L., and Ito, E.: Stable isotope variations in modern tropical speleothems: Evaluating equilibrium vs. kinetic isotope effects, Geochim. Cosmochim. Acta, 68, 4381-4393, 2004.

Mickler, P. J., Stern, L. A., and Banner, J. L.: Large kinetic isotope effects in modern speleothems, Geol. Soc. Am. Bull., 118, 6581, 2006.

Miorandi, R., Borsato, A., Frisia, S., and Zandonati, M.: Monitoraggio di aria e acqua di percolazione in alcune grotte del Trentino, Studi Trent. Sci. Nat., Acta Geol., 82, 151-164, 2005.

Miorandi, R., Borsato, A., Frisia, S., Fairchild, I. J., and Richter, D. K.: Epikarst hydrology and implications for stalagmite capture of climate changes at Grotta di Ernesto (NE Italy): results from long-term monitoring, Hydrol. Process., 24, 3101-3114, 2010.

Mühlinghaus, C., Scholz, D., and Mangini, A.: Modelling fractionation of stable isotopes in stalagmites, Geochim. Cosmochim. Acta, 73, 7275-7289, 2009.

O'Neil, J., Clayton, R., and Mayeda, T.: Oxygen isotope fractionation in divalent metal carbonates, J. Chem. Phys., 51, 5547-5558, 1969.

Polag, D., Scholz, D., Mühlinghaus, C., Spötl, C., Schröder-Ritzrau, A., Segl, M., and Mangini, A.: Stable isotope fractionation in speleothems: Laboratory experiments, Chem. Geol., 279, 31-39, 2010.

Romanov, D., Kaufmann, G., and Dreybrodt, W.: $\delta^{13} \mathrm{C}$ profiles along growth layers of stalagmites: Comparing theoretical and experimental results, Geochim. Cosmochim. Acta, 72, 438-448, 2008.

Rozanski, K., Araguasaraguas, L., and Gonfiantini, R.: Relation between long-term trends of ${ }^{18} \mathrm{O}$ isotope composition of precipitation and climate, Science, 258, 981-985, 1992.

Scholz, D., Muhlinghaus, C., and Mangini, A.: Modelling $\delta^{13} \mathrm{C}$ and $\delta^{18} \mathrm{O}$ in the solution layer on stalagmite surfaces, Geochim. Cosmochim. Acta, 73, 2592-2602, 2009.
Scholz, D., Frisia, S., Borsato, A., Spötl, C., Fohlmeister, J., Mudelsee, M., Miorandi, R., and Mangini, A.: Holocene climate variability in north-eastern Italy: potential influence of the NAO and solar activity recorded by speleothem data, Clim. Past, 8, 1367-1383, doi:10.5194/cp-8-1367-2012, 2012.

Spötl, C. and Vennemann, T. W.: Continuous-flow isotope ratio mass spectrometric analysis of carbonate minerals, Rapid Commun. Mass Spectrom., 17, 1004-1006, 2003.

Spötl, C., Fairchild, I. J., and Tooth, A. F.: Cave air control on dripwater geochemistry, Obir Caves (Austria): Implications for speleothem deposition in dynamically ventilated caves, Geochim. Cosmochim. Acta, 69, 2451-2468, 2005.

Suric, M., Roller-Lutz, Z., Mandic, M., Krajcar Bronic, I., and Juracic, M.: Modern C, O, and $\mathrm{H}$ isotope composition of speleothem and dripwater from Modric Cave, eastern Adriatic coast (Croatia), Int. J. Speleol., 39, 91-97, 2010.

Tremaine, D. M., Froelich, P. N., and Wang, Y.: Speleothem calcite farmed in situ: Modern calibration of $\delta^{18} \mathrm{O}$ and $\delta^{13} \mathrm{C}$ paleoclimate proxies in a continuously-monitored natural cave system, Geochim. Cosmochim. Acta, 75, 4929-4950, 2011.

Wackerbarth, A., Scholz, D., Fohlmeister, J., and Mangini, A.: Modelling the $\delta^{18} \mathrm{O}$ value of cave drip water and speleothem calcite, Earth Planet. Sc. Lett., 299, 387-397, 2010.

Wackerbarth, A., Langebroek, P. M., Werner, M., Lohmann, G., Riechelmann, S., Borsato, A., and Mangini, A.: Simulated oxygen isotopes in cave drip water and speleothem calcite in European caves, Clim. Past, 8, 1781-1799, doi:10.5194/cp-8-17812012, 2012.

Wang, Y. J., Cheng, H., Edwards, R. L., An, Z. S., Wu, J. Y., Shen, C. C., and Dorale, J. A.: A high-resolution absolute-dated Late Pleistocene monsoon record from Hulu Cave, China, Science, 294, 2345-2348, 2001.

Watson, E. B.: A conceptual model for near-surface kinetic controls on the trace-element and stable isotope composition of abiogenic calcite crystals, Geochim. Cosmochim. Acta, 68, 14731488, 2004. 